\title{
A New Look at an Old Petroleum Province
}

\author{
Lee C. Gerhard \\ Kansas Geological Survey
}

\begin{abstract}
New petroleum paradigms in mature basins can be derived from re-examining geological parameters without bias of preceding theory. Kansas has a long history of oil and gas production with over 300,000 wells drilled. Precambrian basement faults in Kansas control the development of later structures, and probably, reservoirs. This study and re-interpretation of geologic history has identified a possible new play along reverse and thrust faults of the Humboldt Fault Zone along the eastern margin of the Nemaha uplift. This paper also suggests that the lack of significant petroleum production in the Salina basin is the result of migration barriers created by faults at the junction of two major fracture trends, rather than by limited local generation and migration.
\end{abstract}

\section{Introduction}

As Kansas oil and gas production declines (Carr, 2002) and consumer demand rises, Kansas has shifted from a net energy exporter to a net energy importer. The oil and natural gas exploration and production industry of Kansas is in decline, and as national energy demands increase, Kansas (still the number-eight producing state in the nation) exemplifies the national production-decline problem. The result of decreasing production is increasing imports, increasing foreign ownership of U. S. assets and means of production, and increased cost of military protection of external supply lines.

Kansas is a mature producing area of the midcontinent. It has undergone several exploration cycles. There are fewer remaining accumulations of oil and gas to find. But petroleum explorationists must be optimists, or there would never be any discoveries. The Crude Oil Potential Committee of the Kansas Geological Survey predicted in 1994 that there were as many as 2.2 billion barrels of oil yet to be discovered in Kansas, in addition to proved reserves at the time of about 300 million barrels (Collins et al., 1994; Gerhard et al., 1992). Certainly some additional production will be developed by new recovery techniques and infield and extension drilling. But where are those undiscovered barrels of oil?

Exploring for petroleum requires constant changes in concepts, in new paradigms. Successful exploration and new development arises from the application of new interpretations of old data, acquisition of new data, and viewing of data in ways not before attempted. Discovery of new plays requires something else: salesmanship of a new concept to management who may view new ideas as difficulties rather than opportunities.
Because Kansas is widely regarded as a mature petroleum province, it is often considered as having been so thoroughly explored and developed that all potential significant pools of petroleum have been found. The exploration experience of this writer has been that although really giant discoveries are rare in old, mature basins, new plays are often successful when old paradigms are discarded and replaced by different ideas. Assumptions of knowledge, things that "everyone knows," are the most stultifying to new ideas. Therefore, this writer has approached the petroleum potential of Kansas without constraints, as if to explore Kansas for the first time.

This approach has precedent. Most petroleum basins or provinces undergo cycles of exploration and development, some driven by technology, others by fortuitous discoveries, and still others through conceptual breakthroughs. In the Williston basin, several new development cycles were established by discovery of new types of traps, but the last several cycles were driven respectively by a fortuitous discovery (Red Wing Creek bolide), economic stimulus (expiring large lease blocks), and new concepts (new structural styles, reservoir studies, and evolution of the basin) (Gerhard and Anderson, 1979, 1988; Gerhard et al., 1982; Gerhard et al., 1991). In turn, without the advent of computer technology, much of the new interpretation could not have been accomplished.

For Kansas, this paper views stratigraphic development in terms of sedimentary sequences without regard to standard geologic time scales. It argues that reservoir development is a function of sedimentary and diagenetic environments, in part controlled by brittle rupture of the Precambrian crust, and that these ancient structural 
discontinuities may be discerned by examination of present-day topography, drainage, and potential fields (magnetic and gravity).

It attempts to identify the fundamental controls on existing petroleum production in order to better predict where similar constraints and opportunities exist. The goal is to provide to Kansas a conceptual framework for re-exploration and new development of the Kansas petroleum resource.

\section{Precambrian Geologic History of Kansas}

The Phanerozoic tectonic pattern that controls sedimentation and diagenesis in Kansas is a direct reflection of its Precambrian history. In consequence, a brief review of that history is appropriate to understanding the development of new play concepts. Bickford and Van Schmus have worked for many years to document the nature, lithology, and age of crystalline and other Precambrian rocks underlying the sedimentary cover of Kansas (Bickford et al., 1979; Van Schmus and Bickford, 1981; Bickford et al., 1986; Van Schmus et al., 1987; Van Schmus, 1992; Van Schmus et al., 1993; Van Schmus et al., 1996) (fig. 1). Some relationship exists between the Precambrian terranes and Kansas structures (fig. 2), particularly between the Central North American Rift and the present day Nemaha uplift and Salina basin. The Central Kansas uplift parallels the boundary between the Western Granite-Rhyolite Province and the Central Plains Province.

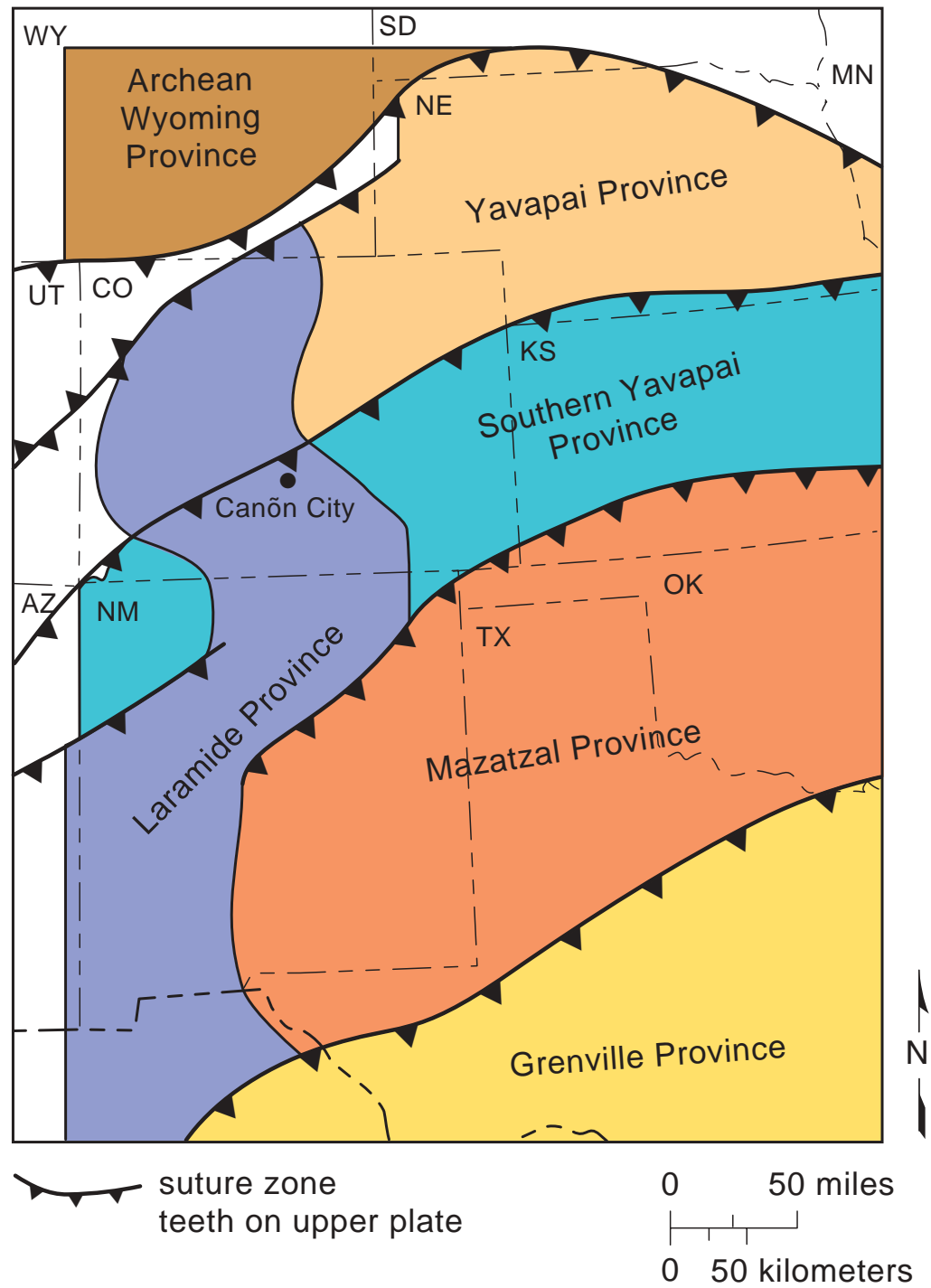

FIGURE 1. Map of southwestern U.S. geologic Precambrian elements, showing provincial names and ages. Modified from CDROM working group (2002). The Southern Yavapai Province is the equivalent of the southern portion of Central Plains Province of Van Schmus et al. (1987) and the Mazatzal Province is the equivalent of the Western Granite-Rhyolite Province of Van Schmus et al. (1987). Carlson and Treves (2000) suggest that Southern Yavapai deformation occurred about 1.67 Ga, and Mazatzal deformation occurred about $1.61 \mathrm{Ga}$. 


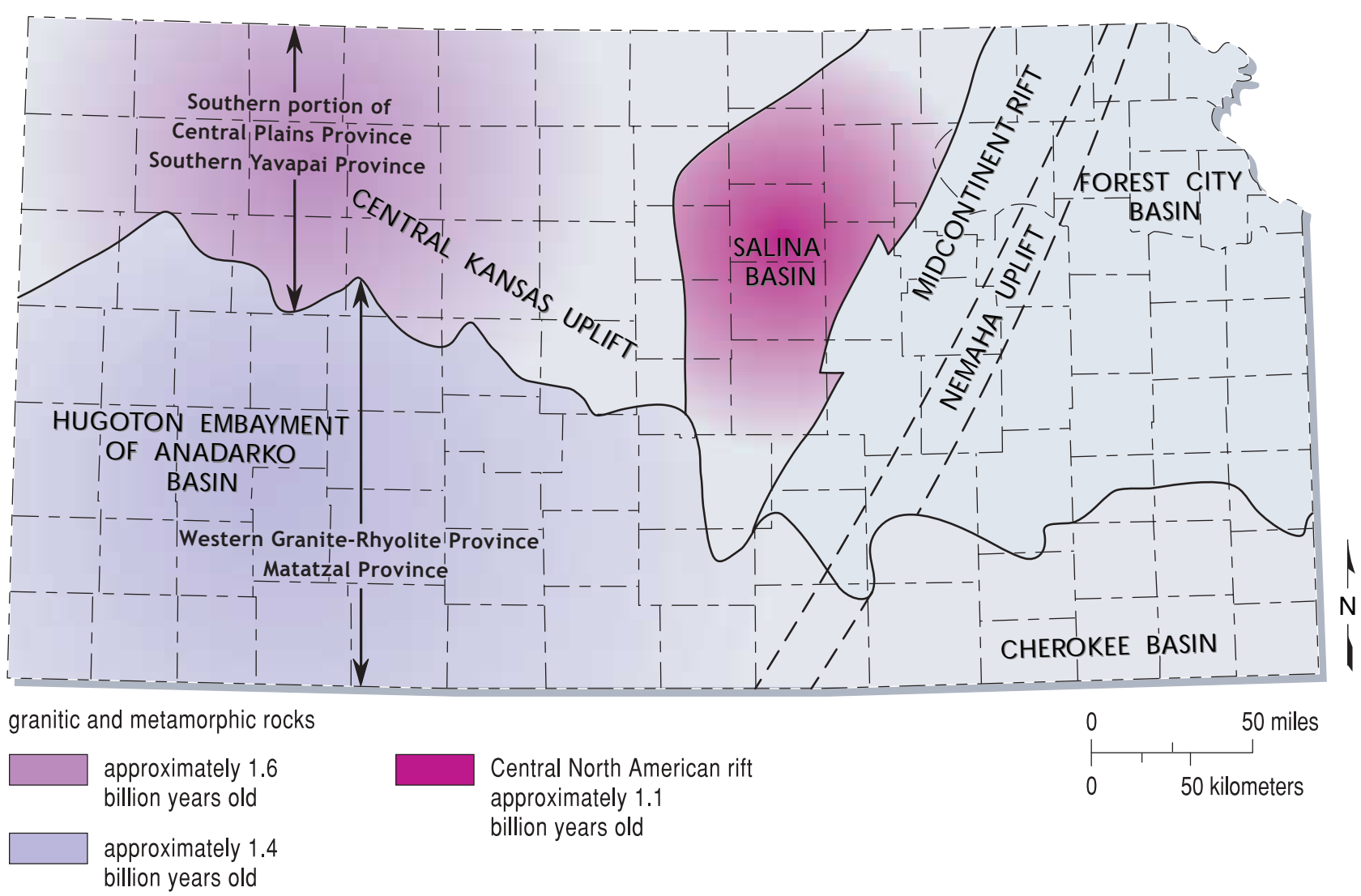

FIGURE 2. Generalized map of Precambrian terranes in Kansas, showing ages and lithologies, with major Kansas historical structures identified. Modified from Newell et al., 1987. Southern portion of Central Plains Province (Van Schmus et al., 1987); Southern Yavapai Province (CD-ROM Working Group, 2002); Western Granite-Rhyolite Province (Van Schmus et al., 1987); Mazatzal Province (CD-ROM Working Group, 2002).

Although early focus was on possible extensional origin of the Kansas Precambrian suite, current thought (Van Schmus et al., 1996; Carlson, 1999, 2001) is that these rocks record the last of a series of Paleoproterozoic (greater than $1.55 \mathrm{Ga}$ ) and Mesoproterozoic (younger than $1.55 \mathrm{Ga}$ ) accretionary episodes, the last additions of juvenile crust to the region. Cooling of the region by 1.3 Ga should have permitted brittle fractures to develop (Van Schmus, personal communication, 2003). several interpretations of additional accretionary belts (Carlson and Treves, 2000; Carlson, 2001) and variations about where the major boundary contacts between belts occur (CD-ROM Working Group, 2002; Carlson, 2001; Carlson and Treves, 2000; Newell et al., 1987) have been made. Because a significant active structural discontinuity between the accretionary terranes does not seem to exist, the exact placement of the boundary is likely not important to this study. The presence of patches of metamorphosed sedimentary rocks throughout the approximate $1.6 \mathrm{Ga}$-old northern terrane of Newell et al. (1987) in Kansas (southern portion of the Central Plains Province of Van Schmus et al. [1987]) suggests that incomplete assimilation of these former sedimentary rocks is unique to the northern terrane. The southern granitic province (ca. $1.4 \mathrm{Ga}$ old) (the Western GraniteRhyolite Province of Van Schmus et al. [1987]) is younger and has so far yielded no metasedimentary rocks. Thus the boundary may be defined by the presence or absence of metasedimentary rocks (given sufficient sampling points).

CD-ROM Working Group (2002) maps (fig.1) suggest that their Southern Yavapai Province includes both the southern portion of the Central Plains Province of Van Schmus et al. (1987) and the closest Precambrian exposures in Fremont County, Colorado, where a thick section of meta-sedimentary rocks is exposed. These rocks apparently represent at least one full continentalscale sedimentary sequence. Although it is not possible to develop a strong correlation between Kansas Precambrian rocks and the Colorado rocks except on an approximate age of metamorphism and intrusion, it may be possible to interpret a more detailed geologic history of the Central Plains Province than is possible from the cuttings and cores that have been collected in the Kansas portion of the province. It is especially tempting to theorize correlation of quartzites of the Gorham field area (Walters, 1991) with those exposed in the southern Rocky Mountains. Van 
Schmus (1992) argued that the northern portion of the Central Plains Province (Orogen) is an eastward extension of a primary crustal accretion complex found in northern Colorado; perhaps the southern portion is represented in central and southern Colorado exposures (CD Working Group, 2002).

The last Precambrian rock generation occurred in the Late Proterozoic, in the Midcontinent Rift System. Basic sills, basaltic flows, and arkosic sedimentary rocks with some organic shales (Berendsen et al., 1988) were emplaced during 1.2-1.1 Ga (Van Schmus et al., 1987; Van Schmus, 1992).

The change in tectonic style from accretion of successive volcanic arcs to extensional tectonics (formation of the Midcontinent Rift System) appears to have set the stage for a brittle-failure Phanerozoic structural style. While it is not possible to accurately date the formation of most fractures in the basement rocks of Kansas, study of betterexposed rocks elsewhere can assist in interpretation of structural history. Over the last four decades, studies have documented the influence of early structural failure upon Phanerozoic sedimentation and structural development (Gerhard, 1967; Gerhard et al., 1982; Gerhard et al., 1987; Gerhard and Anderson, 1988; Gerhard et al., 1991; see also references cited in those publications).

Baars et al. (1995) suggested that the entire North American craton was fractured by wrench faults during the later Proterozoic, prior to 1.2-Ga rifting. Gerhard et al. (1991) have argued that movement along wrench faults in the Williston basin has generated the major petroleumproducing structures in that basin, and formed many of the Wyoming Rocky Mountain structures as well.

Whether those arguments will remain viable in the future is uncertain, but the concepts have led to significant petroleum discoveries and explanations for patterns of both production and lack of production. Berendsen (1999) has documented in detail rhombic fracture sets in northeastern Kansas (see also Plate 1, this paper). Marshak and Paulson (1996) also argue that Precambrian wrench-fault-originated rhombic blocks are precursors to Phanerozoic structures. Carlson (1999) has argued that many cratonic structures are simply rejuvenation of prePhanerozoic weakness planes, an argument with which this writer has no quarrel. The principle embodied in this discussion may be stated:

Structural distortion of previously consolidated cratonic plates is accommodated largely by rejuvenation of planes of weakness originally formed after plate cooling. The relative sense of motion along these fractures will vary with the directions of stress applied at the margins of the plate during later accretionary or rifting events.
The Midcontinent Rift Sytem appears to have a present day vertical relief of over $20,000 \mathrm{ft}$; that is, it contains extrusive, layered intrusive and sedimentary rocks of approximately 20,000 ft in thickness, deposited in grabens and crustal gaps (Berendsen et al., 1988; Serpa et al., 1989; Woelk and Hintze, 1991, 1995; Van Schmus et al., 1996). Van Schmus (1992) has theorized that the stratigraphic section of basic intrusives and red sandstone encountered in the Texaco \#1-31 Poersch well (Washington County, northeastern Kansas) is reversed by thrust faulting.

Van Schmus' evidence for reversal of lithologic section is 1. Normally, in exposed portions of the rift (northern Michigan), detrital clastics overlie layered basalts and basic sills.

2. Some of those sections have been reversed by thrust faulting.

3. At the top of the Poersch well, igneous rocks are directionally reverse-magnetized.

4. A U-Pb date of $1,097.5 \pm 3 \mathrm{Ma}$ was obtained from the top of the igneous-dominated section penetrated in the Poersch well, congruent in age and magnetism with equivalent volcanics and intrusives in the Lake Superior area (Van Schmus, 1992).

Because the underlying sedimentary rocks in Kansas have not been dated nor their polarity identified, it remains possible that in Kansas there is a lower detrital section and the upper detrital sediments, coeval with those of the Lake Superior region, have been eroded. However, correlations made by Van Schmus suggest strongly that the section is thrusted. COCORP data (fig. 3) illustrates possible thrust faulting, along with possible sedimentary "packages."

If thrusting occurred, the mechanics of conducting overthrusting in the confined space of a graben are intriguing. There are two obvious models. The first requires continued downdropping and tilting of the floor of the graben, fracturing the accumulated section. Mass movement of the relatively elevated mass over the downdropped mass, with subsequent erosion of the sediments on the top of the upper plate can accomplish the reversal of section without any re-orientation of stress fields.

The second model requires driving the thrust within the graben by significant crustal shortening, prior to deposition of Phanerozoic rocks. This model might result in creation of additional splayed thrust faults around the margins of the rift as well as shortening the crust within the riftIf present, these splays might be rejuvenated at a later date.

Carlson (1997) argues that the central graben topography was reversed so that central horsts existed with 
accompanying downdropped flanking graben basins. Basalt associated with the horst development is dated at $990 \mathrm{Ma}$. This interpretation requires vertical tectonics rather than compressional thrusting and does not provide for the inversion of sediment and volcanic packages as argued by Van Schmus (1992).

A clear gap in the continuity of the rift system exists near the Kansas-Nebraska border (Carlson, 1997). The lithologic sequence in the Kansas portion of the rift system possibly results from differences in process and history from that of the remainder of the western limb of the MRS in Nebraska through Minnesota; certainly, a difference in prior Precambrian tectonic history is found within these areas. Perhaps the Kansas segment is more aligned with the detailed history of the Oklahoma aulacogen, and this discussion compares non-correlative sections. Interpretation of COCORP seismic information suggests, but does not prove, thrust faulting.

\section{Identifying Structural Directions}

Although Kansas has no exposures of its Precambrian rocks, more than 1,000 drill holes have sampled the Precambrian. Cole (1976) used that control and extrapolated control based on the top of the Arbuckle and other tests to construct a basement-configuration map of the Precambrian subcrop. Cole mapped numerous normal faults that he identified by well control. The present topographic relief on the top of the Precambrian surface reflects the major geologic structures of Kansas (fig. 4).

Analysis of early structures in Kansas can be found in Merriam (1963), Baars (1995), and Berendsen (1999) and their citations. Serpa et al. (1989) published seismic profiles through the Midcontinent Rift that illustrate their interpretation of the normal fault geometries responsible for the downdropping of the rift bottom, a series of moderately dipping normal faults (fig. 5).

The residual portion of the rift graben in Kansas containing Precambrian sedimentary and layered igneous rocks (Rice Formation [Scott, 1966]; see Bickford et al., 1979; Bickford et al., 1986 for distribution) lies well to the west of the most pronounced present-day topographic/ structural anomaly of the Precambrian surface (but of Pennsylvanian elevation). That anomaly, the Nemaha "Ridge," trends north-northeast through the eastern third of Kansas. Berendsen (1997) named several fault zones that cut the Nemaha and summarizes much that is known about the displacement on each. Adjoining the Nemaha at nearly right angles, trending northwest, is the Central Kansas uplift, the other major positive relief structure in the subsurface of Kansas, which connects to the Cambridge Arch in Nebraska. The juncture of these two structures, the Midcontinent Rift/Nemaha Ridge and the

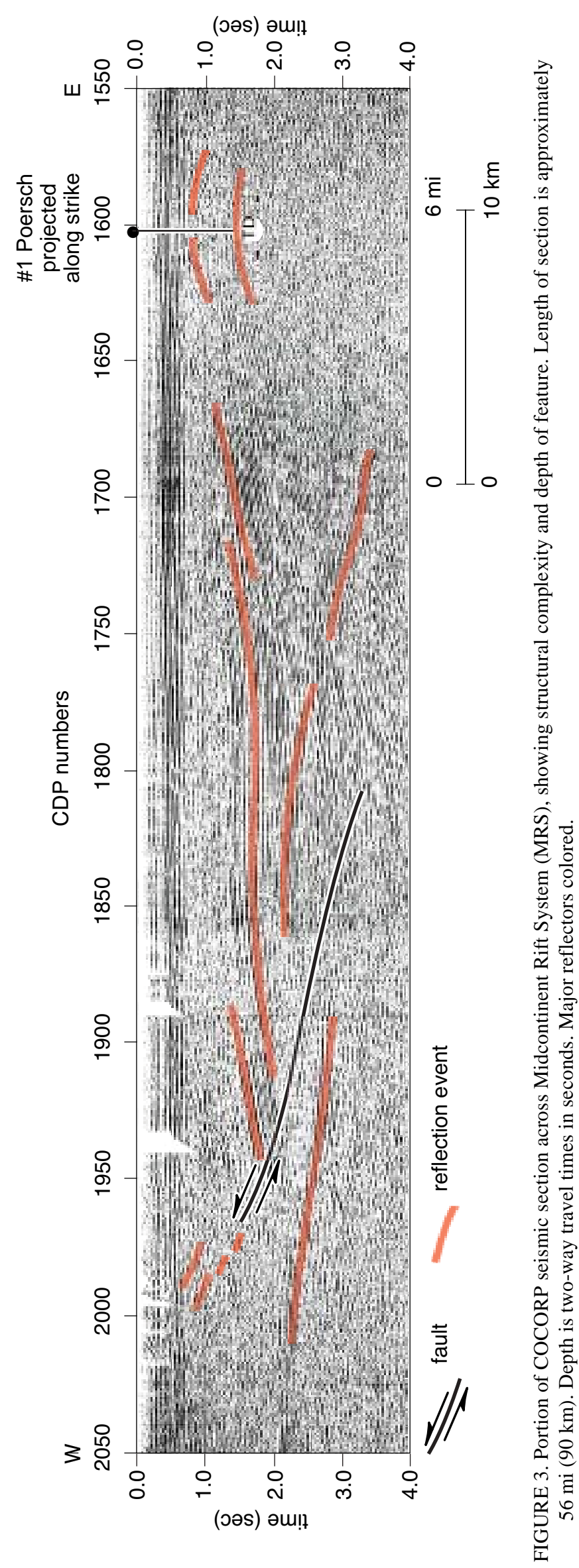




\section{Gerhard 6}

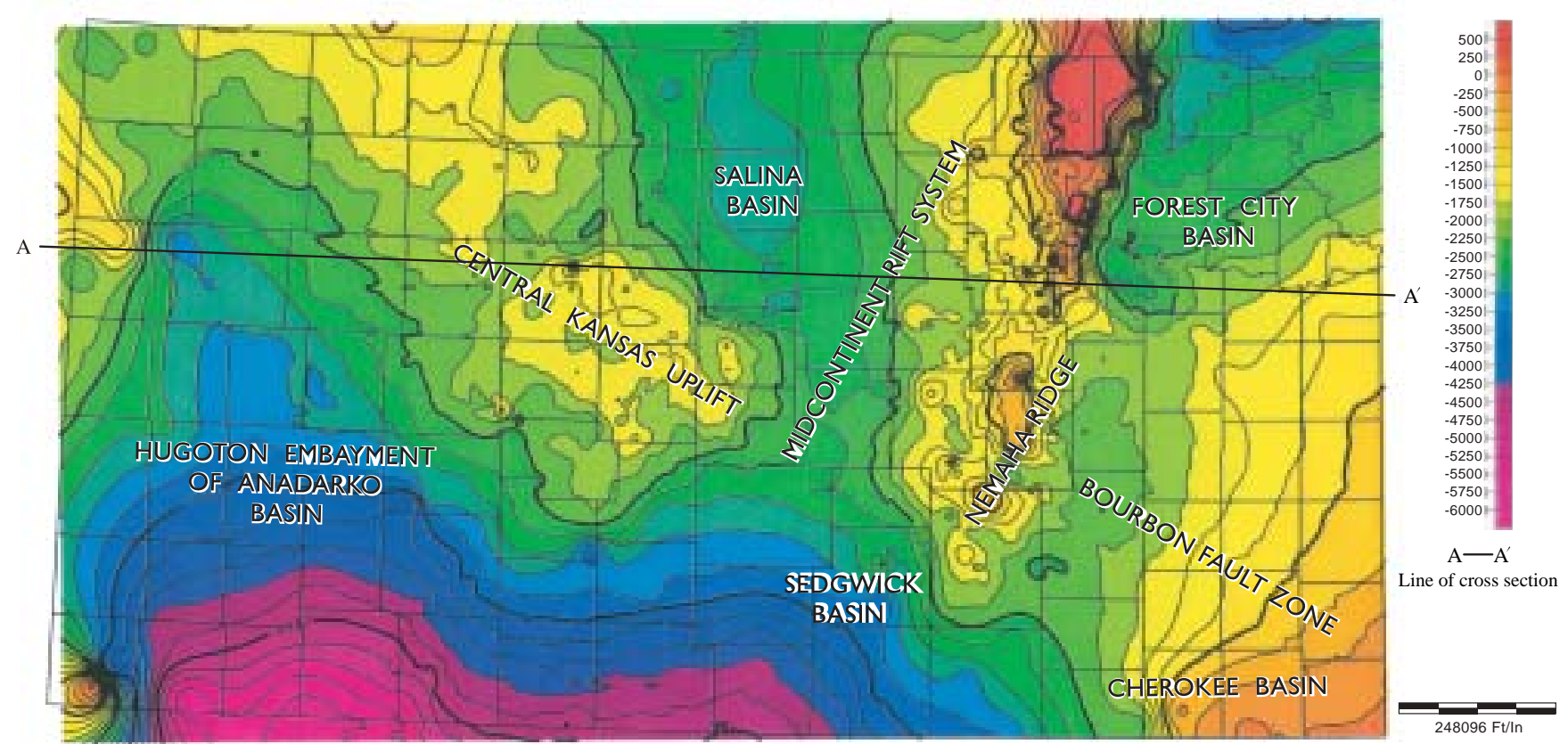

FIGURE 4. Map showing topographic (structural) relief on the present Precambrian/Phanerozoic surface. Major geologic structures of Kansas are labeled (T. Carr, personal communication, 2003). A-A' is line of section for fig. 5.

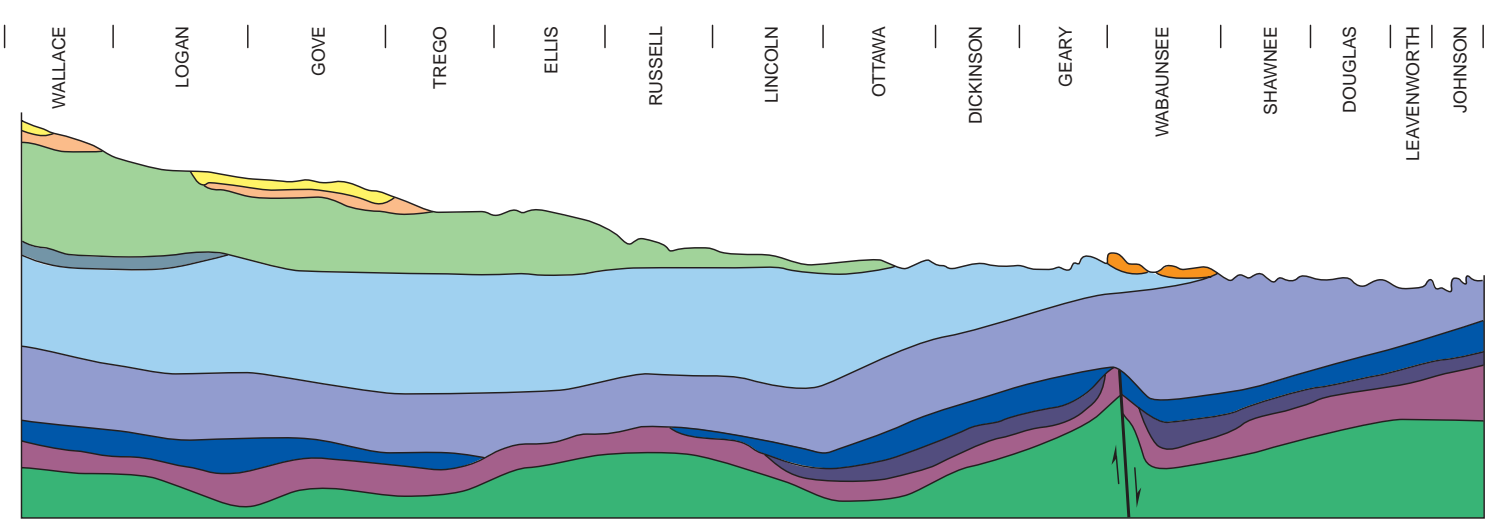

Geologic cross section below I-70
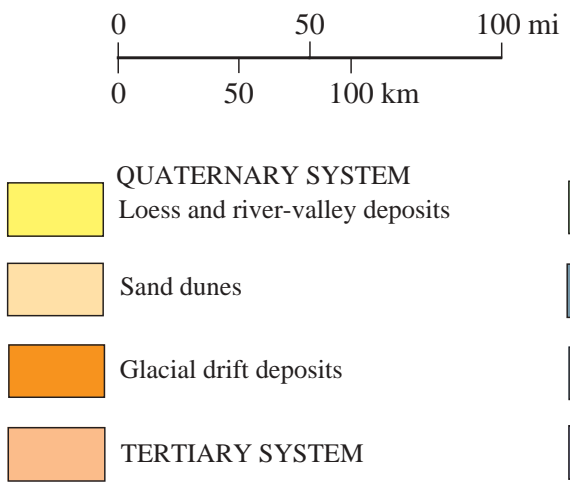

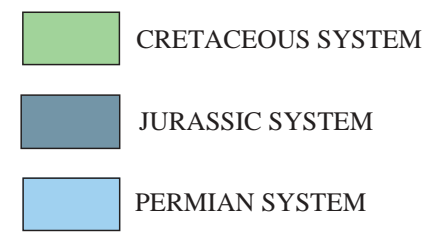

PENNSYLVANIAN SYSTEM

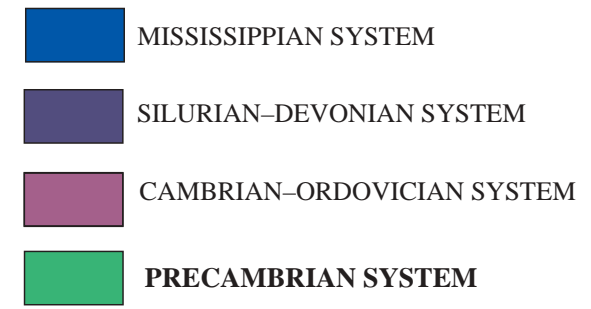

FIGURE 5. Diagrammatic cross section across Kansas showing normal faulting along the Nemaha, the traditional interpretation. Kansas Geological Survey. Line of section is A-A' on fig. 4. 
Central Kansas uplift, forms the southern entrance to the Salina basin.

\section{Identifying and Locating Phanerozoic Fracturing and Faulting}

Identification of structural "grain" and linear structures in the deep subsurface requires integration of several data sources. One of the most powerful of these data sources is drainage pattern analysis, particularly in areas where there has been a history of reactivation of older structural trends, and when coupled with other tools. In this study, drainage pattern analysis of major stream segments was combined with earlier subsurface geologic mapping and slope changes (Cole, 1976), and potential fields data (gravity and magnetic data of Lam and Yarger, 1989, and Yarger, 1989; see also Kruger, 1996). Previous studies in eastern Kansas have identified structural elements and directions that are incorporated in and corroborated by this study (Baars, 1995; Berendsen, 1997; Berendsen and Blair, 1986; and Burchett et al., 1983).

Inden and Frush (2002) and Silverman (2002) have recent documented examples of use of potential field information for interpretation of structural "grain." The underlying Precambrian framework of Kansas is a highly fractured complex of crystalline rocks and younger, still Precambrian, detrital sediments that have been faulted and eroded prior to the Sauk transgression (latest Precambrian through Lower Ordovician). The fractures are in two major sets, north-northeast trending and northwest trending. The north-northeast-trending fractures are the major controls for the Midcontinent Rift System, and include the present day Nemaha Ridge and parallel structures such as the Abilene anticline (fig. 6; plate 1). West of the Nemaha Ridge and the Rift System, the trend is more northeast than north-northeast, and the fracture sets appear to be normal conjugate shears.

Subsequent Phanerozoic tectonic activity has undoubtedly modified Precambrian structures. Berendsen (1997) cites tectonic events that terminate the Sauk Sequence, Tippecanoe Sequence, Lower Kaskaskia Sequence (Gerhard et al., 1982), and Upper Kaskaskia Sequence. All these events can be related to craton margin events, whose stress is reflected in strain within the craton (Gerhard et al., 1991) (see also brief note by Wilson and McCauley, 1989).

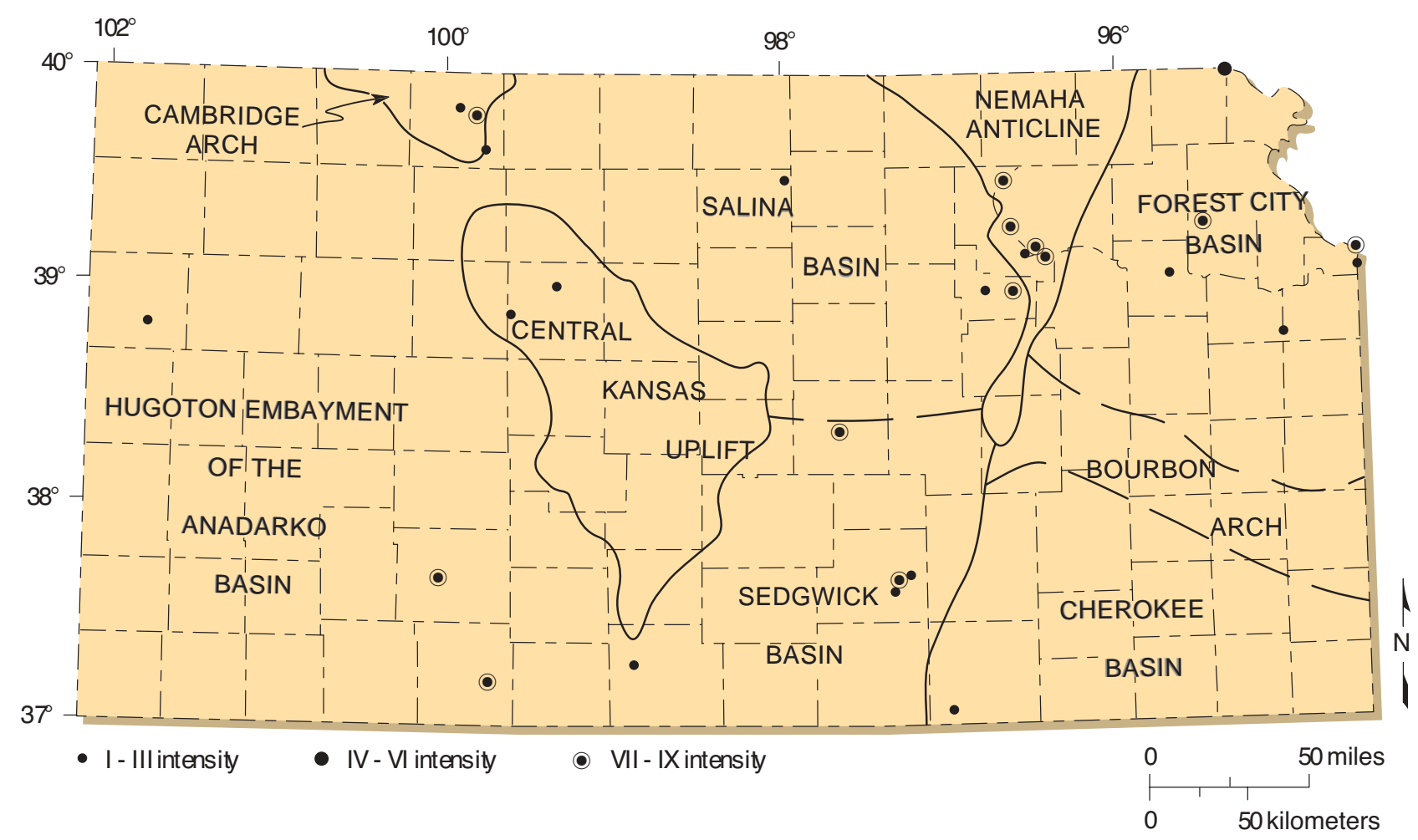

FIGURE 6. Generalized geologic structures of Kansas, showing the historical outlines of major structures and epicenters of major earthquakes. Modified from Merriam (1956), with earthquake epicenter additions from Steeples (1996). Steeples also documented locations of epicenters of microearthquakes, many associated with the Nemaha Ridge and the Central Kansas uplift. 
The relative frequency of these events confuse dating the origins of the two major tectonic "grain" trends. Some Midcontinent Rift faults are offset by northwest-trending faults, but this may reflect only the most recent relative motion along these faults. As Berendsen (1997) has pointed out, there is a lateral component to some of the stress fields, so that it is not possible to date the origin of the fractures.

It is apparent from plate 1 that the major basement structures of Kansas are bounded by fractures that may have both Precambrian and Phanerozoic histories. As pointed out by Hambleton (1989), along the rift system sedimentary thickness variation indicates that at least some of these fractures had Phanerozoic movement. Rhombic blocks are developed by conjugate shearing. Typically these blocks have a slight vertical rotation, giving rise to subtle influence on deposition, especially in carbonate settings. Junctions of faults may exhibit topographic/structural behavior at odds with surrounding terranes. One example of this phenomenon is the junction of the two faults interpreted from Arkansas River drainage pattern on plate 1 . Here, the apparent junction is also the location of the Cheyenne Bottoms Wildlife Refuge, a large wetlands (approx. $19 \mathrm{mi}^{2}$ ) that is geomorphically anomalous. There are many more fractures on and along the Central Kansas uplift than have been mapped. Plate 1 is not designed to identify every possible fracture, but rather to identify the major detectable fractures and their apparent density. It is clear from the linear pattern of oil drilling on the Central Kansas uplift that additional fractures are present (see also Baars and Watney, 1991, and Berendsen, 1999).

Relative direction of motion along the fractures is unknown. The sense of direction has probably changed over time, the last major movement being postMississippian (Ancestral Rocky Mountain tectonism). Roehl et al. (1989) identified reversed last motion on the Lyons anticline in Rice County, Kansas, at the southeastern end of the Central Kansas uplift in a seismic profile. Their cross section shows significant thickness variation in lower Paleozoic rocks near the faults, indicating that the structural history is likely complex (see also Carr et al., 1995). It is unclear that there has been any Laramide re-adjustment along any of these planes. This is congruent with knowledge of other cratonic basins of Colorado and North Dakota (Baars, 1966; Gerhard, 1967; Gerhard et al., 1987). Identification of reversal of sense of motion along major structures and thickness changes in associated sedimentary units is key to diagnosis of recurrent movement on older planes of weakness.

Wrench-fault motion is much more difficult to identify. As Berendsen (1997) has pointed out, there is a lateral component to some Kansas stress fields, the full extent of which cannot be determined. As a purely speculative concept, it might be possible that the extensive northwesttrending Humbolt Fault Zone, fronting the east flank of the Nemaha Ridge, together with elements of the Midcontinent Rift, has a significant strike-slip (wrench) component. If so, the Bourbon Arch (Merriam, 1963) could be the offset extension of the Central Kansas uplift, but that motion would require a cumulative relative offset of approximately $66 \mathrm{mi}$, and is suggested here only to illustrate the conceptual power of fracture reconstruction. Further detailed study of the history of specific sets of fractures may lead to better understanding of the potential for economic mineral and energy deposits along the Nemaha and much of the rest of Kansas. Berendsen (1997) suggests that an extension of the Missouri Gravity Low that accommodates the offset between the Kansas and Nebraska sections of the Midcontinent Rift can be traced under the rhyolites of the St. Francois Mountains of Missouri.

If accurate, this could date the origin of the northwesttrending faults as older than the 1,480 MA age of the rhyolites. Very recently, McBee (2003) suggested significant strike motion along the entire length of the Nemaha, from Oklahoma to Nebraska.

\section{Petroleum Implications of Precambrian and Later Tectonism}

The ultimate purpose of this study is to identify potential exploration targets that may be developed through study of the Precambrian rocks of Kansas, their tectonic setting, and their interaction with later events. There are several effects that pre-existing rocks and structure may have on subsequent petroleum-reservoir development and migration pathways. One is simply a topographic prominence being the focus of compaction of overlying sediments, creating thinning and draping. Similarly, marine transgression around a topographic prominence may create an apparent offlap of coeval sediments, reflecting the shoaling of water on the flanks of the prominence. Diagenetic reservoir enhancement may occur through the concentrations of fluids moving through the sedimentary body and along the basement/sediment surface, culminating at the top of the prominence.

If the topographic prominence is due to tectonic movement, recurrent movement will likely result in depositional thickness variations between high and low areas, and some younger rocks may be displaced by faults. This can create either permeability increases or barriers, may juxtapose reservoir rocks against sources, or, especially in carbonate rocks, create differential porosity zones. Other possibilities exist. Frequently, combinations of several of these possibilities co-exist and create complex reservoir settings. Migration of petroleum 
fluids can be controlled by pre-existing fracture sets (Gerhard et al., 1991, for instance).

One of the enigmas of Kansas petroleum production is the lack of significant production from the Salina basin (fig. 7). Exploration geology requires optimism, but optimism must be tempered with economic reality.

In this case, although there has been significant exploration drilling, production has been confined to the margins of the Salina basin, peripheral to and along major blocks of the Central Kansas uplift and the Nemaha uplift, and in smaller fault-bounded structures. There are apparently two major oil sources: Ordovician and Devonian (Rich, 1931, 1933; Newell and Hatch, 1999) (see also Gussow, 1954), derived from Arbuckle and Simpson, and Chattanooga equivalent rocks, respectively. The Newell and Hatch study suggests local generation of oil may occur along major offsets such as the McPherson anticline, whereas the remainder of the Salina basin is likely too shallow to have caused any significant generation. The hypothesis presented herein is that the intersection of fractures of the Nemaha and Central Kansas uplift form a structural barrier to migration, so that oil moving from the south is shunted along the major fractures to fill reservoirs on and along the uplifts. These fractures create a migration shadow in the Salina basin (fig. 8) where oil is barred from the basin by the shunts.
Walters (1958) and Price (1980) both advanced the theory of long-distance migrations of oil from the Anadarko basin to central Kansas through Arbuckle rocks, during the mid-Permian. Their model calls for decreasing amounts of oil and gas to be emplaced northward as traps fill and correspondingly decrease the supply of petroleum for more northerly traps. The barriers to migration model suggested herein simply adds one more complication to the migration story and does not assume a restricted supply of petroleum from the Anadarko.

Exploration drilling requires reservoir rock, trap, and source. This hypothesis suggests that a source is missing in the Salina basin, and it is not economically feasible to continue exploration drilling in the basin barring demonstration of a potential source. If there is a source, it is likely to be local, barely mature, and of small volume (Newell and Hatch, 1999).

The concept of structural-migration shadows has been demonstrated elsewhere, such as in the Williston basin (Gerhard et al., 1991), where diffusion migration alone cannot explain the occurrence or lack of occurrence of petroleum (fig. 9).

Oil and gas migration along preferred pathways of high permeability, whether lithologic or structural, provides for long-distance migration, almost a prerequisite for

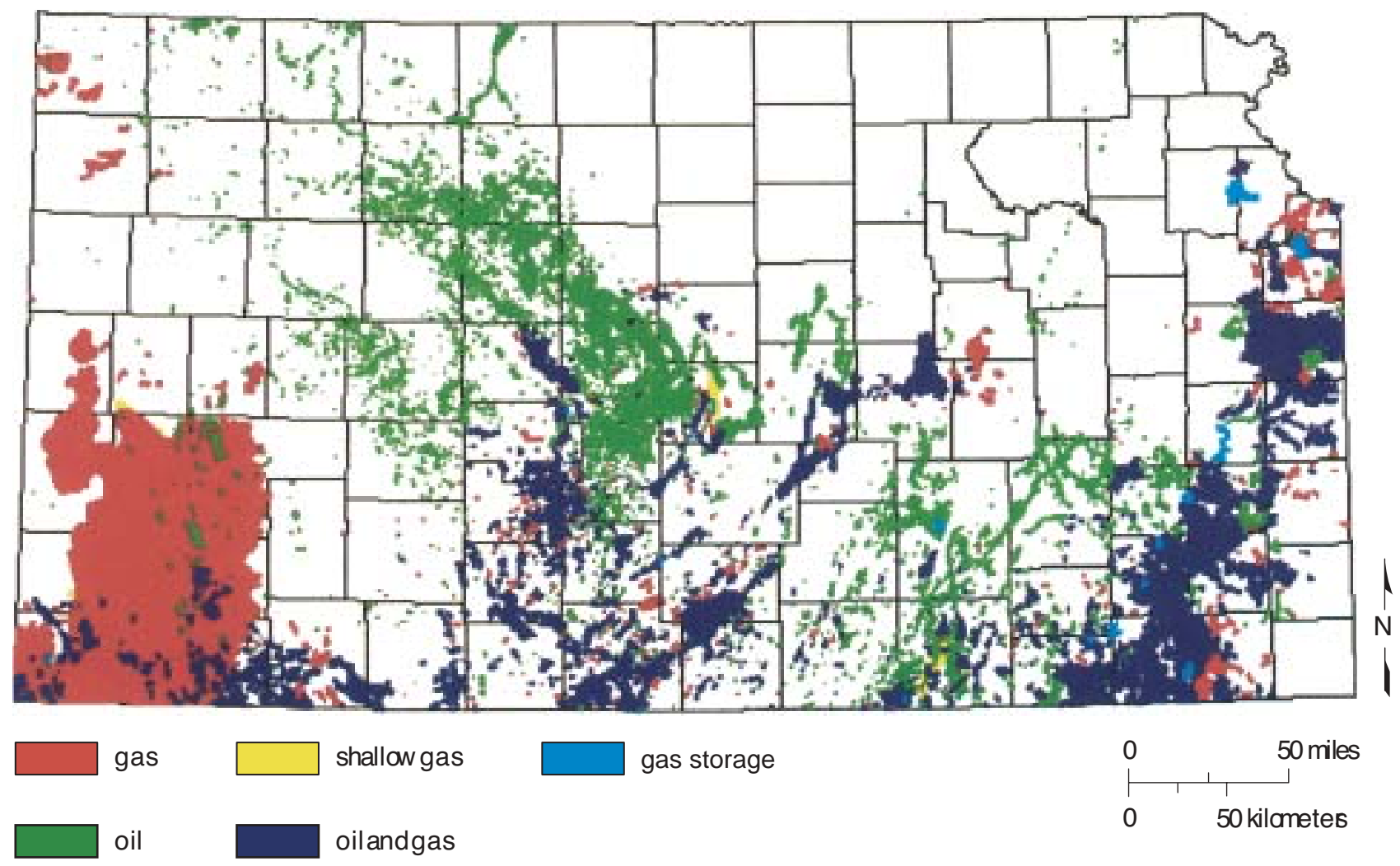

FIGURE 7. Generalized oil and gas map of Kansas. Kansas Geological Survey map. 
significant accumulations of petroleum in shallow cratonic platform accumulations where depth of burial cannot provide the necessary heat and pressure to crack organic sedimentary content into petroleum. Newell and Hatch (1999) argue for juxtaposition of source beds and reservoir along faults on the McPherson "anticline," which they demonstrate to be an uplifted reverse-faulted block. They demonstrate that Ordovician oils are probably local, and of low relative maturity, coupled with Chattanooga oils that indicate maturity of source rock, and thus, longer-distance migration from south to north.

Thick accumulations of sediments lie south of Kansas, early Paleozoic accumulations in the tectonic troughs of eastern Oklahoma and western Arkansas, and younger thick deposits in the Anadarko basin in western and central Oklahoma, extending into southwestern Kansas. These "piles" have generated huge amounts of petroleum, from Ordovician rocks in the east (Arbuckle and Simpson Groups) and Devonian in the west (Chattanooga Shale and anoxic equivalents). Early ideas (Rich, 1931, 1933; Gussow, 1954) of long-distance migration have been recently validated (Walters, 1958; Price, 1980; Burruss and Hatch, 1989). Local generation may emplace significant amounts of oil, but the billions of barrels of oil produced in Kansas so far are likely to have migrated long distances from their source beds.

\section{Review of the Nemaha Ridge: A New Look at an Old Structure}

The Nemaha "Mountains" (Moore and Haynes, 1917; Moore, 1918) are a buried range of the Ancestral Rocky Mountains in eastern Kansas. The current elevation difference on the Precambrian surface between the

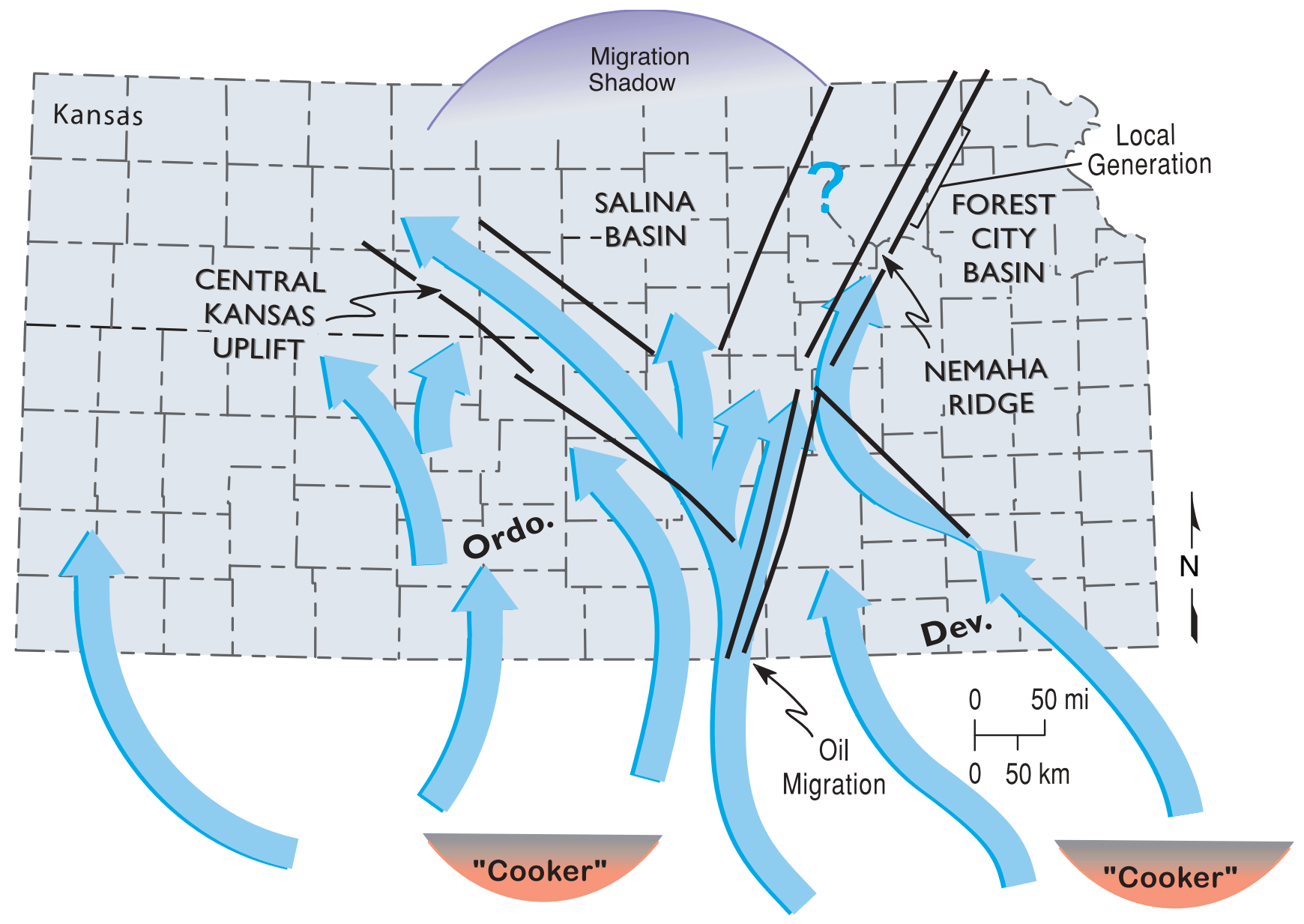

FIGURE 8. Migration patterns and shadow map, showing approximate migration pathways for oils generated in the Ouachita and Anadarko basins, and local generation in the Forest City basin. Migration shadow is Salina basin, where migration was shunted away from the basin by faults into the Central Kansas uplift and the Nemaha Ridge. 


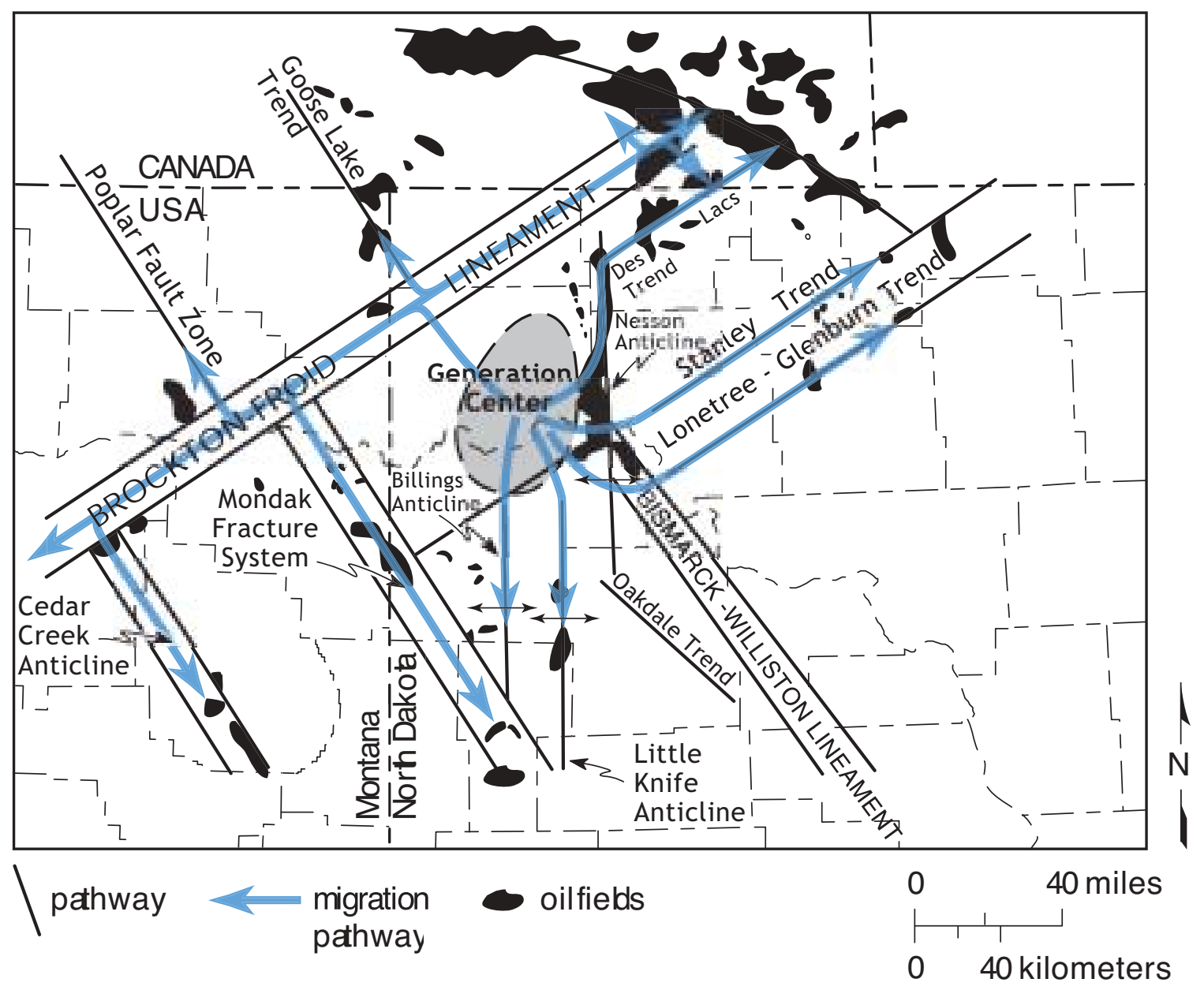

FIGURE. 9. Migration patterns in the Williston basin, North Dakota, Montana, and South Dakota, showing the influence of fractures and faults on migration. Oil is generated in the middle of the basin and migrates along fractures. This explains the linear accumulations and the lack of oil accumulations in portions of the basin intermediate in position between the source area and the known accumulations. From Gerhard et al. (1991).

remnant peaks and the valley below and to the east is over 3,300 ft in Nemaha County and over 2,300 ft in Wabaunsee and Pottawatomie counties (Cole, 1976). If there were travelers in eastern Kansas during the exposure of these mountains in the Pennsylvanian, the mountains would appear much as the present-day Front Range and Rocky Mountain peneplain do today to travelers to Colorado Springs and Denver. The subsurface topographic expression of this feature gradually decreases to the south, and there is little relief on the Precambrian/ Paleozoic surface in Sumner and Cowley counties.

The eastern margin of the Nemaha is faulted (see for instance, Cole, 1976). The north portion of the eastern fault system in northeastern Kansas has been referred to as the Humboldt fault (Condra, 1927; Jewett, 1951), but segments of the fault system are traceable from north to south across the entire state. The system commonly has been portrayed as a series of normal faults (Kansas Geological Survey, 2000, for instance; Burchett et al.,
1983). Merriam (1963) noted that the faults were likely both normal and reverse, but little note was taken of that description at that time.

It is the hypothesis of this paper that the Nemaha uplift is a reverse-faulted, perhaps thrust-faulted, structure, with the fault planes on the eastern margin dipping west. The consequence of this hypothesis is that petroleum-bearing reservoir rocks may underlie the thrusts (reverse faults) and may prove to be more productive than the reservoirs that have been discovered on the upthrown side of the faults. Further, there is the possibility that antithetic and back thrusting may occur on the western margins of the Nemaha and that these structures may also prove productive, if charged.

The Nemaha structure lies sub-parallel to the late Precambrian Midcontinent Rift System, a gravity anomaly that runs approximately $40 \mathrm{mi}$ to the west of the Nemaha, and which contains at least $20,000 \mathrm{ft}$ of detrital clastics, basic sills, and basalt flows. The geometry of the system 
and the fact that the Nemaha appears to have movements affecting sedimentation and erosion during the lower Paleozoic strongly suggest that the Nemaha has origin in the same tectonic regime as the original Midcontinent Rift System.

Lyons (1959) studied the gravity fields of the region, and designated a gravity anomaly he noted as the "Greenleaf Anomaly" for its maximum gravity anomaly of +15 milligals near Greenleaf in Washington County. He correlated it with gravity anomalies from Oklahoma's Anadarko basin to Lake Superior, a system now known as the Midcontinent Rift System, but theorized that this was an intracontinental "tectogene." In time context, plate tectonics was 10 years off, and geosynclinal theory could not explain features such as this. The observations and correlations of that time are valid today, but now fit into a unified theory of earth tectonics, plate tectonics, not yet known then. Overlapping sedimentary rock bodies and erosional truncation along the Nemaha argue for an active history throughout the lower Paleozoic (Lyons, 1959). The major tectonic movement forming the present-day Nemaha appears to be post-Mississippian and preDesmoinsian (Lyons, 1959; Jewett, 1951; Merriam, 1963), coincident with eastern seaboard tectonism and the coeval cratonic "Ancestral Rockies" deformation (see Burgess et al., 1997, for orientation of margin subduction).

Along its length, the Nemaha is broken by cross faults and apparent shears of northwest trend, some of which control the geometry of the Central Kansas uplift (Cole, 1976)

(plate 1). Some of these cross faults have a vertical component resulting in knobs or monadnocks along the crestal trend. Further evidence that there is a vertical component to these cross faults is found in eastern Kansas along faults that trend northwest through Linn, Franklin, Shawnee, and Waubunsee counties (Merriam et al., 1958; Merriam, 1960; Merriam and Smith, 1961). Merriam (Merriam, personal communication, 2003) has seen up to 2,000 ft of either Precambrian or Cambrian sandstone in well samples on the north side of the fault, not present on the south side (Rogers \& Slane \#11 Paul Tholen. SE NW SW sec. 34, T. 23 S., R. 21 E., Allen County). The well previously was drilled to $4,505 \mathrm{ft}$; new projected TD is $6,500 \mathrm{ft}$ ). It is located only $18 \mathrm{mi}$ from the Iola "Deep Well" that encountered 1,329 ft of sand and sandstone below the Arbuckle without reaching crystalline rocks (Haworth and Bennett, 1908). Merriam (personal communication, 2003) also stated that he has mapped up to $8 \mathrm{mi}$ horizontal displacement along one of these faults, separating the Elmdale and Burns domes (interpreted from the map by Cole, 1976). Berendsen (1997) comments that the lateral component of motion is always greater than the vertical displacement along the cross faults, in both Missouri and in Kansas (p. 236).
The importance of the cross faults to the tectonic history of the Nemaha is that these faults represent northwesttrending probable pre-Phanerozoic wrench fracturing of the Kansas crust, along directions that approximate many of the major structures of Kansas (especially those of the Central Kansas uplift and sub-structures contained therein), followed by crustal extension that formed the north-northeast-trending Midcontinent Rift System. The rift appears to have undergone repeated deformation (Serpa et al., 1989) (fig. 10).

It is not possible to accurately date the rifting, as outlined previously. However, the rift fill has been in turn severely deformed, including by large-scale thrusting (Van Schmus, 1992; Woelk and Hinze, 1995), and lower Paleozoic rocks thin over the Nemaha. This suggests continued and persistent activity from the origin of the feature through to at least Desmoinesian time, when the present subsurface topography of the Nemaha was established. Minor reactivation continued through the present, accounting for drainage linearity. Cross fault right-lateral motion concurrent with or after uplift of the Nemaha is apparent at Elmdale and Burns domes, where Lansing Group rocks are downdropped $700 \mathrm{ft}$ relative to the Elmdale dome, and apparently translated right lateral nearly $8 \mathrm{mi}$ (Merriam et al., 1958; Merriam, 1960; Merriam and Smith, 1961).

For a quiet cratonic region, Kansas has had an active tectonic history.

Thrusting in the rift (as earlier described) is of special interest here because the rift thrusts may be precursors to Paleozoic reverse faulting. Woelk and Hinze (1995) illustrate an interpretation of the rift in cross section that is thrust faulted on both sides (their fig. 9, reproduced here as fig. 11). The minimum displacement of the western fault (dipping east) is about $6 \mathrm{mi}$ horizontally and 0.5 seconds vertically (two-way) (fig. 12). Using velocities of $5.5 \mathrm{~km} / \mathrm{sec}$ for basalts, and $4.3 \mathrm{~km} / \mathrm{sec}$ for well-indurated sandstones, and assuming that $50 \%$ of the section is each, the vertical displacement is about 1.23 $\mathrm{km}$, or $1 \mathrm{mi}$. That implies that the dip of the thrust averages about $15 \infty$. We have previously discussed the possible origins of the thrusts, but the upthrust horst created by these faults almost specifies that the origin must be crustal shortening owing to the stress field changing from extension to compression. Figure 11 indicates that the west-dipping thrust may be ramped. Nothing in the data supports or denies interpretation that these thrusts are pre-existing faults that have been reactivated.

Reconstruction of the Midcontinent Rift based on the schematic cross sections of Serpa et al. (1989) (fig. 10) with crustal shortening added to the original rift extension and movement occurring along reactivated original 
normal faults demonstrates that the Nemaha is likely to be a reverse-faulted anticlinal structure. This is structural behavior similar to structures mapped in the Colorado Ancestral Rocky Mountains (Gerhard, 1967) (fig. 13). This diagram provides a model to test normal-fault models against reverse-fault models.

The probability of reverse faulting is theoretically high. Bump (2003) has argued that the geometry of many Rocky Mountain Laramide structures may be related to shallow basement failure linked to reactivation of preexisting fractures. Many of the surface expressions may be neotectonic elements resulting from reactivation, rather then direct reflections of the original structures.
The major deformation of the Nemaha took place in preDesmoinesian and post-Mississippian time (Lee, 1943; Merriam, 1963). If the entire vertical relief of the structure were visible at one time (as previously described), it would be an imposing structure. Merriam considers that it was more likely a range of lower-lying hills and ridges, inferring that sedimentation of debris eroded from the hills (mountains) filled the valleys as the range was elevated, subduing the topographic relief. Lee further describes a series of small movements along the fault system, starting in pre-Pennsylvanian time with truncated Mississippian rocks, and abrupt thickness changes in the Cherokee section of at least $900 \mathrm{ft}$ (Lee, 1943, p. 124). It is likely that there was significant relief

\section{PRE-RIFT BASEMENT}
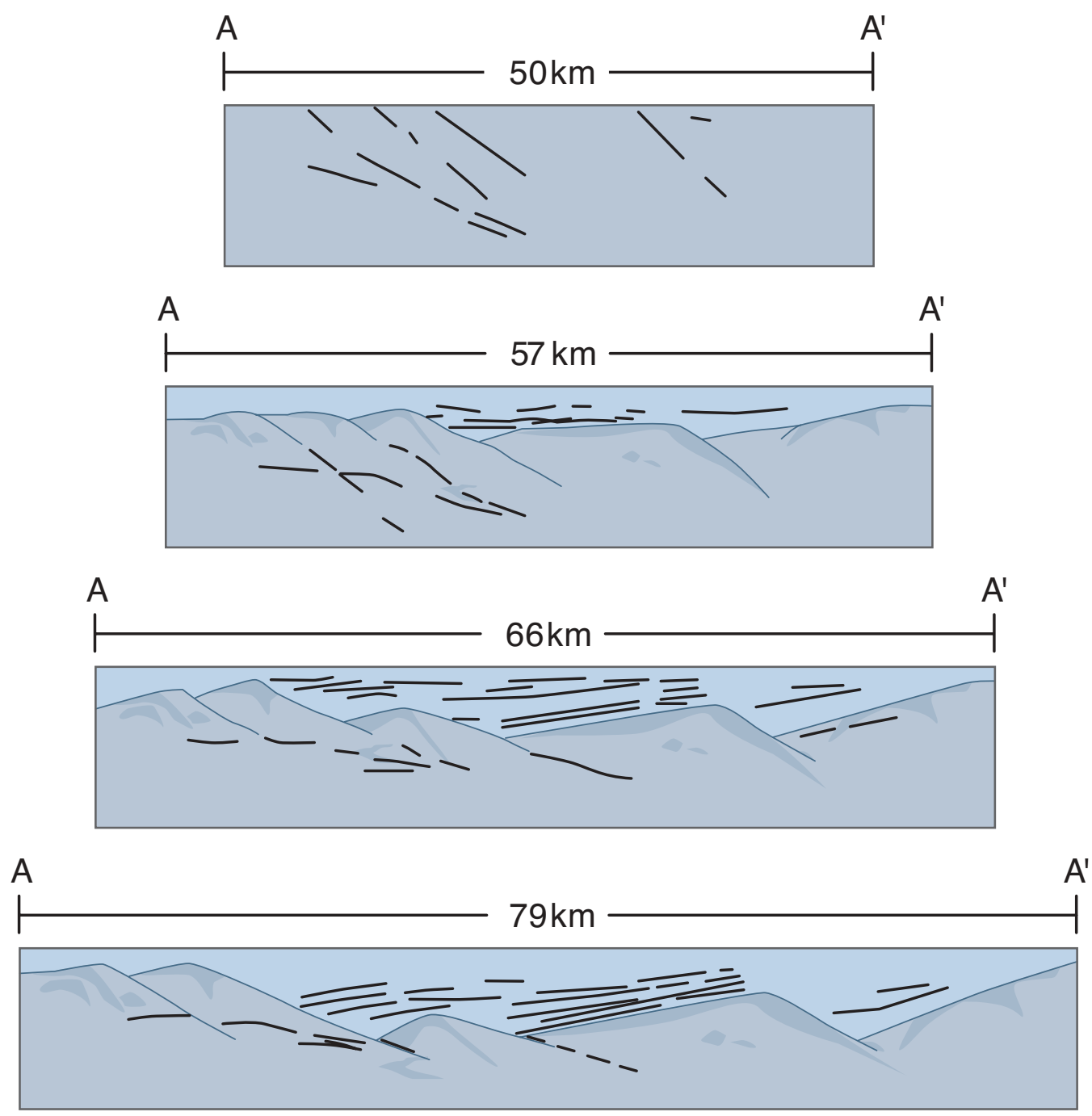

POST-RIFT BASEMENT

FIGURE 10. Serial generalized cross sections from Serpa et al. (1989), showing geometric sequence of extensional events that resulted in the rift. 


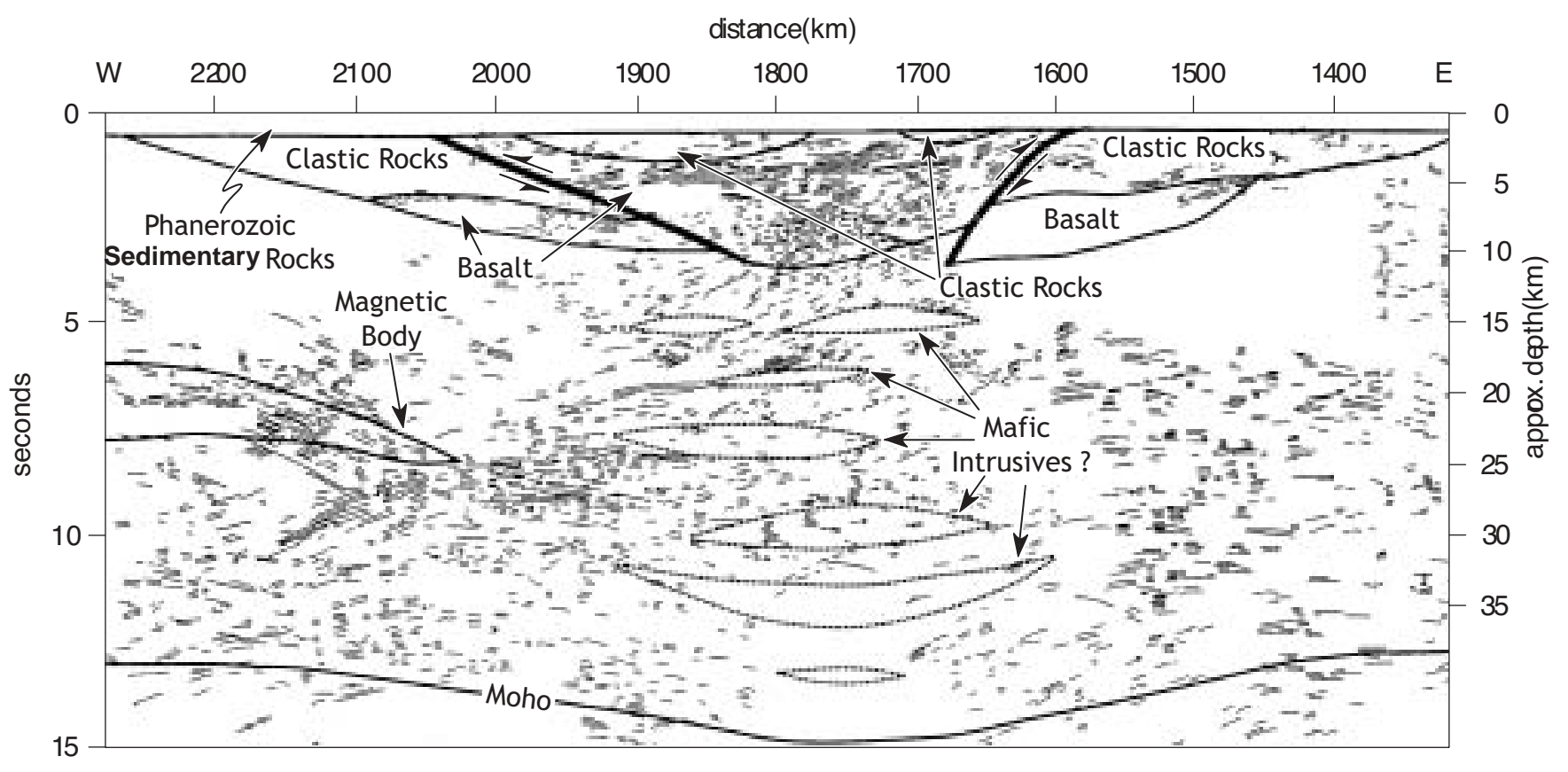

FIGURE 11. Diagrammatic cross section across the Midcontinent Rift System, showing thrust faults along the west and west sides of the rift. From Woelk and Hinze (1995).

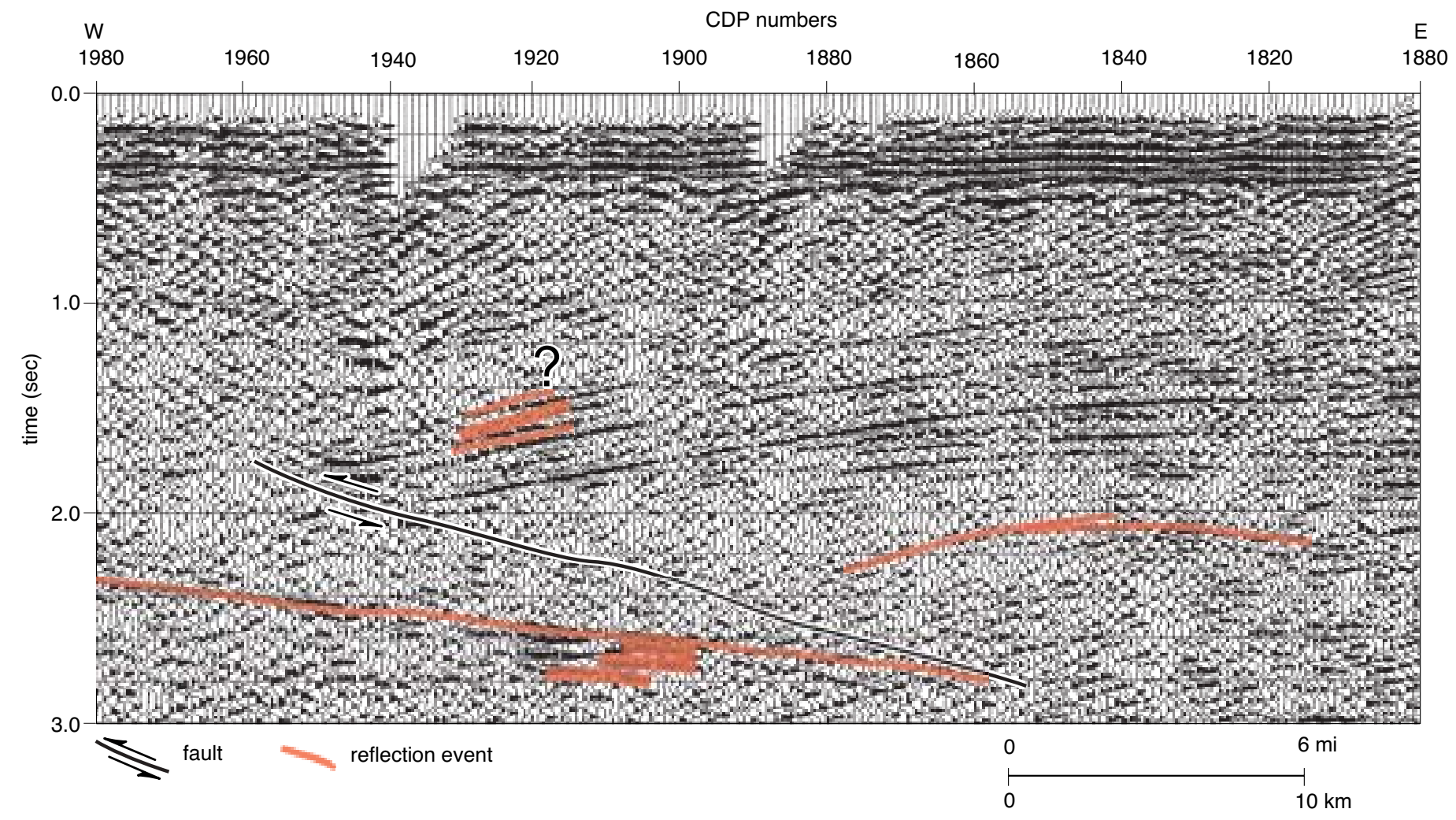

FIGURE 12. Detail of COCORP seismic section across the Midcontinent Rift System, showing western east-dipping thrust fault. Vertical displacement appears to be about $1 \mathrm{mi}(1.6 \mathrm{~km})$, and horizontal displacement is at least $6 \mathrm{mi}(9.6 \mathrm{~km})$. 


\section{POST-COMPRESSION BASEMENT}

A

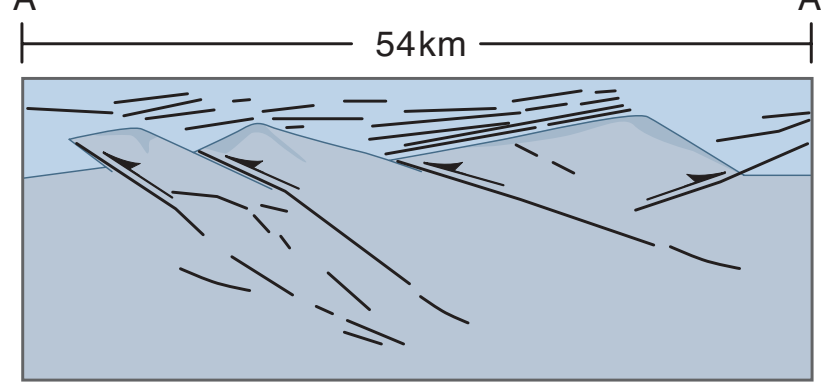

FIGURE 13. Post-compression model of Midcontinent Rift System showing possible resulting fault geometries. The reconstruction is based on the model of Serpa et al. (1989) (fig. 10), and uses the same failure planes.

at various times along the Nemaha, but the full structural displacement may never have been topographically expressed at any one time.

Except for the Nemaha structure, the Precambrian/ Phanerozoic surface of the Midcontinent Rift System is of generally low relief. There are several hills of a few hundred feet on that surface, in Marshall, Riley, and Marion counties (Cole, 1976), possible remnants of older topography. No rift features seem to have been sufficiently rejuvenated during the pre-Demoinesian tectonic episode so as to leave a topographic signature on the Precambrian/Phanerozoic surface, although there is a distinct valley corresponding to the major eastern border fault of the rift (Burchard fault of Carlson, 2001).

The shape of the Nemaha in cross section (along the boundary between R. 10 and $11 \mathrm{~S}$.) shows the geometry of the block and its western complementary platform (fig.
14). Based on present topographic expression, the Nemaha is apparently scissored, hinging in northern or central Oklahoma, and having maximum displacement in northern Kansas and southeastern Nebraska, where Carlson (2001) shows it to terminate against successor structures to the Penokean Orogen.

The sense of motion along the Humboldt and other eastern boundary faults of the Nemaha is at issue. As previously argued, many current maps show the fault system to be normal, that is, the hanging wall has moved downward with respect to the footwall. It is difficult to visualize the rest of Kansas being dropped down relative to the Nemaha. Several lines of inquiry suggest that the faulting is reversed, or possibly thrusted.

1. The stress field of the midcontinent during the postMississippian and pre-Desmoinesian was compressional, with the deformation of the Appalachian margin occurring from the east, and the northwarddirected Ouachita deformation following on the southeast and south. Normal faulting requires an extensional stress field.

2. Reversals of structure are well documented in the literature, much of which has already been cited. Figure 13 portrays a compressional reconstruction of the rift.

3. Significant thrust faulting has been interpreted in the rift system by Woelk and Hinze (1995). Van Schmus (1992) has argued that there is reversal of stratigraphic section in the rift and that it is the result of thrust faulting.

4. Earthquake epicenters in Kansas are clustered about the Nemaha (Steeples, 1996). Although strong earthquakes are extremely rare, the frequency of measurable earthquakes along the Nemaha and the Central Kansas uplift argue for continued crustal

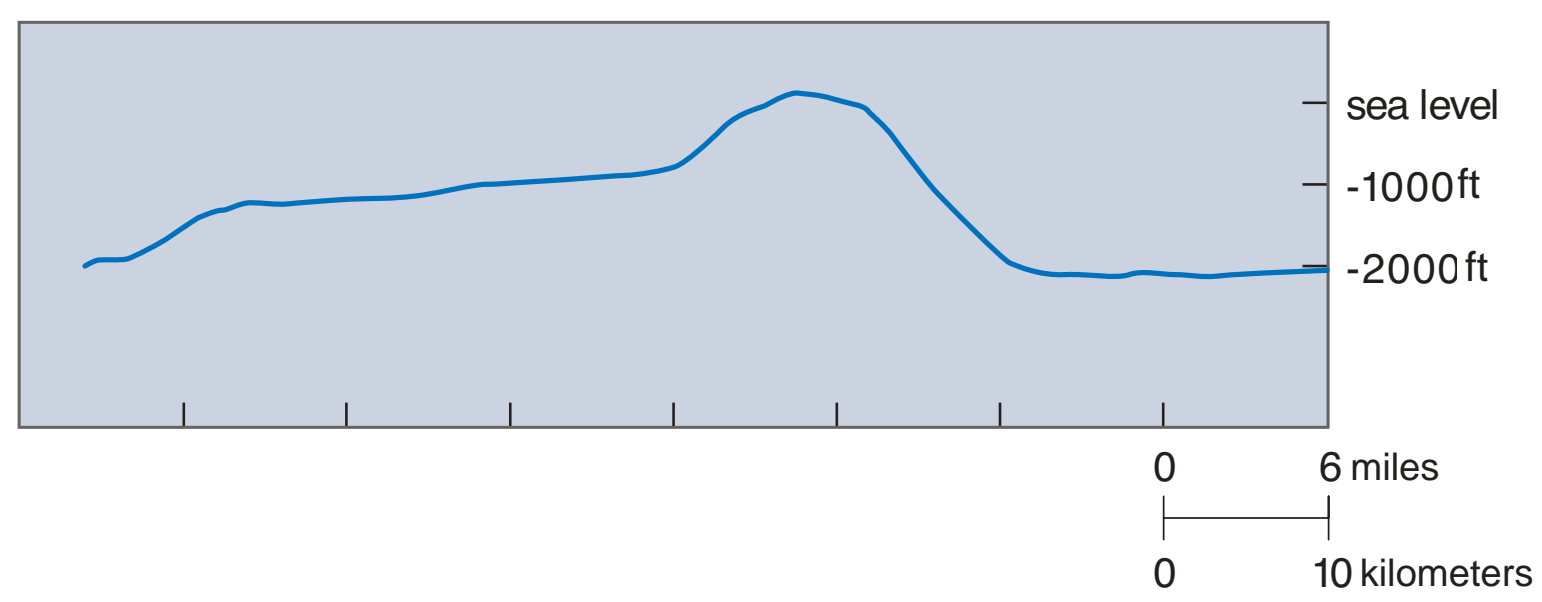

FIGURE 14. Topographic profile of the Precambrian/Phanerozoic surface along a line between R. 10 and 11 S., in Geary and Waubunsee counties. Vertical exaggeration is 1:47. Line of section approximately $42 \mathrm{mi}$ long. The unusual two-tiered configuration of the surface indicates that reverse faulting and "pop-up" of the Nemaha may be a rational solution to the model. 
instability and adjustment to plate-boundary stresses. Further, the epicenters of the Nemaha-related earthquakes appear to lie well to the west of the Humboldt fault, suggesting movement along a westdipping thrust underneath the Nemaha (Merriam, 1956).

5. Many reported drill holes encountered reverse faulting, as indicated by repeated section. Discussion follows.

Numerous examples of reverse faults in Kansas are documented in the literature, most associated with the Midcontinent Rift and the Nemaha. Merriam (1963) noted that there were high-angle reverse faults and normal faults along the margin of the Nemaha. Earliest notation of reverse faulting in the literature is Bunte and Fortier (1941), who identified reverse faulting on the McPherson (Voshell) anticline, and Smith and Anders (1951), who documented reverse faulting on the east side of the Nemaha. More recently, reverse faults have been documented in a number of locations.

Roehl et al. (1989), interpreting a seismic line across the Lyons anticline in Rice County (at the eastern end of the Central Kansas uplift), suggest that the feature had a Keweenawan history as a broad symmetrical feature, a pre-Chattanooga movement, and a major late Mississippian or early Pennsylvanian deformation. That deformation resulted in the development of a reverse fault on the western side of the feature, dipping east, illustrated as a double reverse fault (their fig. 2). Haraldson et al. (1995), using the same seismic line, illustrate the reverse fault in more detail, with geologic supporting data. They also illustrate the Precambrian precursor structure.

Carr et al. (1995) document a reverse fault along the southwestern margin of the Central Kansas uplift in the Hampton field, with a vertical displacement of 100-150 m (328-492 ft). This fault is accompanied by an anticlinal fold on the upthrown block, in the theoretical position of a reverse-fault drag structure. The line of section is eastwest, the dip is to the apparent south. Time of maximum displacement is pre-Arbuckle, which continues over the fault without interruption, although that horizon is folded. Carr et al. (1995) interpret that folding to be compactionrelated rather than tectonic, although slight adjustments on the fault may not be discernible in the seismic data.

One county east Newell and Hatch (1999) have demonstrated oil accumulations to be the result of complex faulting along the north-south-trending McPherson anticline (including the Voshell field). They document both reverse and right-lateral movement along the main bounding fault, with a vertical throw of up to $400 \mathrm{ft}(125 \mathrm{~m})$. Individual pools are separated by cross faults that create closures. This demonstration of fault complexity is one of the few examples of lateral fault movement in Kansas. Strike-slip fault movements are likely frequent, but they are largely undetected because of the difficulty of geologically discerning such motion.

Newell (1996) also has studied the Paleozoic history of this system in detail. He found that there has been reversal of motion along the main fault, that is, down to the east, during early Paleozoic time, preserving younger portions of the Viola Formation and Silurian-Devonian "Hunton" beds. Newell also suggests that there is left-lateral motion along the Pratt anticline that is a relict of the Midcontinent Rift, and thus the Pratt structure may be a remnant portion of the western margins of that zone. Berendsen and Blair (1986) have argued that the Nemaha may be a sinistral (left-lateral) feature.

Gay (1995, 1999, 2003a, 2003b) has argued that the Nemaha is reverse faulted, providing both potential field interpretations of interacting terrane blocks (Gay, 1995) and numerous examples of reverse faulting derived from study of well logs (Gay, 1999) (fig. 15). He extended his study into Oklahoma, where the Nemaha structure is less apparent at the Precambrian/Phanerozoic surface. Gay considered that the Nemaha is a complex structure with thrust and strike-slip motion, although he gave no theoretical or regional context for that opinion, instead relying on the examples of reverse-fault motion from well logs, and from potential-fields study (fig. 15). His example of a 6-km (4-mi.) left-lateral offset in central eastern Kansas along the Nemaha is an important data set to establish the theoretical left-lateral motion (fig. 16), as has been the work of Berendsen and Blair (1986).

Gay makes several concluding points that are germane to this discussion. He argues, rightfully, that the tectonic origin of the Nemaha is in the Ancestral Rocky Mountain orogenesis, although he fails to relate that activity to the overall compressional regime of the AppalachianOuachita-Marathon deformation and the much earlier formation of the Midcontinent Rift System. Gay used many examples from the Rocky Mountain region to illustrate his viewpoint. Gay also has used the Kansas COCORP data to illustrate what may be thrust faults in the deep subsurface that could be "causative" faults for Nemaha reverse faulting. Gay also believes that the eastbounding fault is steeply dipping near the surface, but is a listric fault that dips much less steeply with depth. The present writer has had extensive research experience in the Ancestral Rockies and has previously had success in using the reverse-fault nature of Ancestral Rocky Mountain structures for finding petroleum accumulations.

Gay (1999) argues in his abstract that the Nemaha is a "pop-up" structure and that back thrusts are to be expected. The data supporting that statement are the presence of eastward-dipping thrusts along the McPherson anticline (Voshell anticline) in McPherson County so well documented by Newell and Hatch (1999). 
Since completion of the first draft of this manuscript, Gay has published additional work arguing the the Nemaha tectonically reflects earlier Paleozoic eastern North America deformation and documenting additional compressional structures (Gay, 2003a, 2003b).

\section{Nemaha Models and Petroleum Potential}

Possible models of deformation across the Nemaha include normal faulting, reverse faulting, thrust faulting (lower-angle reverse motion), and combinations of faults with both senses of directions (fig. 17). As an example of the complex fault nature of the Nemaha, Baars and Watney (1991) present a detailed map of interpreted faults in the Kansas subsurface from study of well logs and structure mapping. Berendsen (1999) interpreted a portion of the area in extreme detail in northeastern Kansas, although the direction of dip of faults may vary from his initial diagnosis (fig. 18).

In all cases, the models suggest that west-dipping reverse faults bound the east flank of the Nemaha, rather than normal faults. The petroleum implication of the suggested structural geometries is that potential oil and gas traps
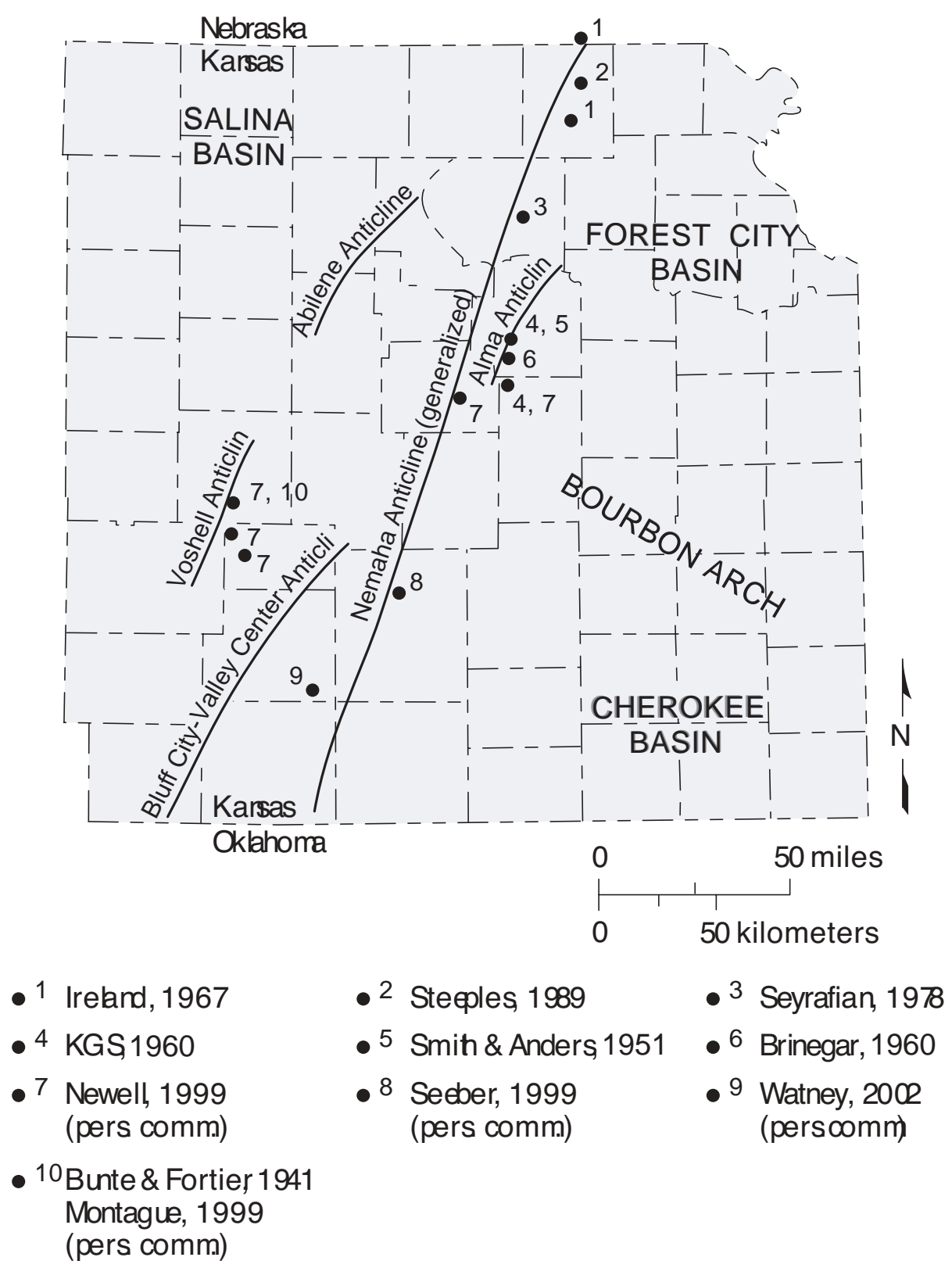

FIGURE 15. Location of known reverse faulting in Kansas along or associated with the Midcontinent Rift. Modified from Gay (1999). 


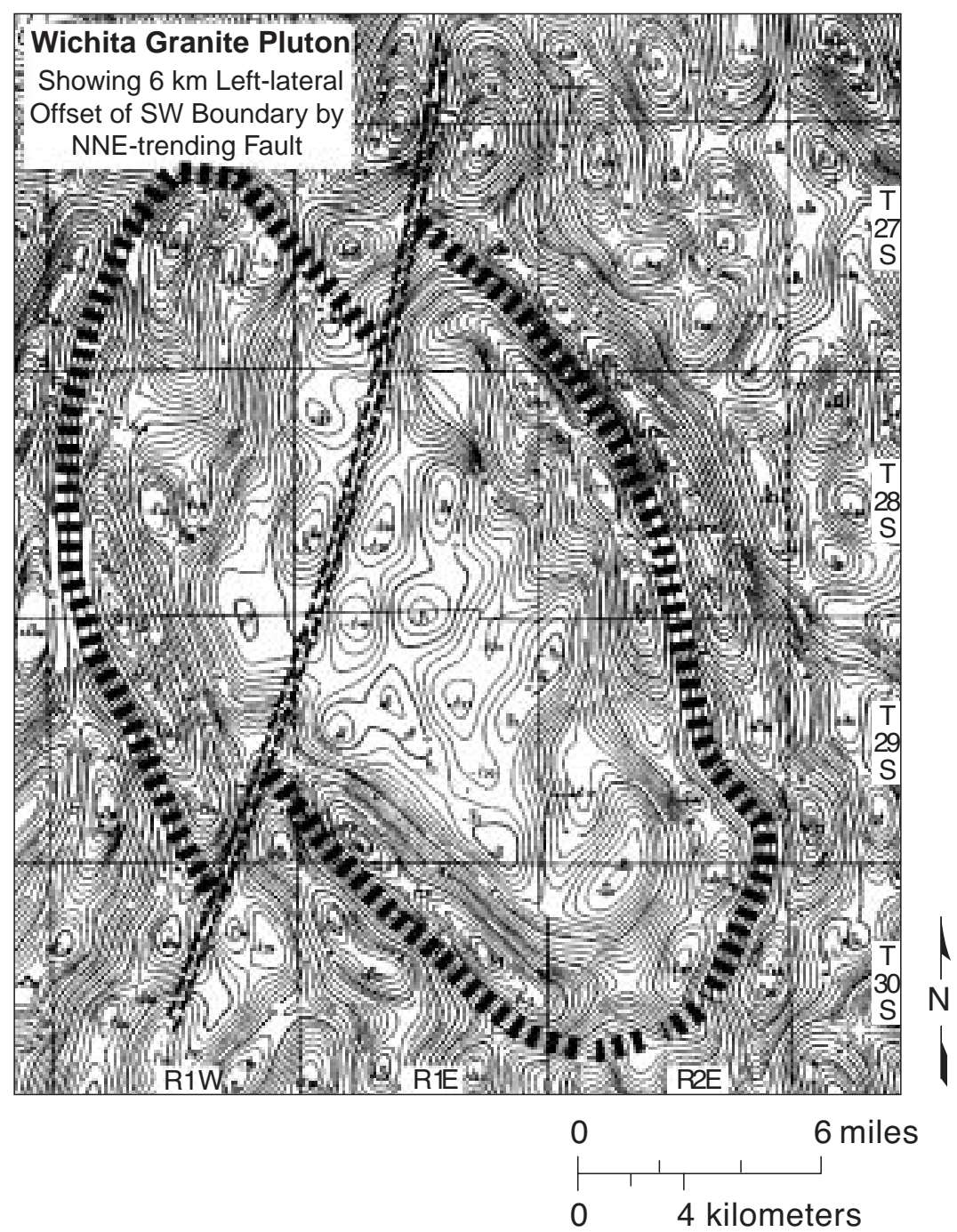

FIGURE 16. Interpreted left-lateral offset in the Wichita igneous complex, northern Sumner County, Kansas, demonstrating leftlateral wrench faulting along the southern portion of the Nemaha. Gay interpreted $4 \mathrm{mi}(6 \mathrm{~km})$ of offset to have occurred contemporaneously with the uplift of the Nemaha. From Gay (1999).

exist in reverse or thrust models that are not present in any normal faulted model. Arching of the upper plate to create structural closure, capture of slices of lower plate rocks and folding of lower plate rocks with consequent closure, stratigraphic and fault plane trapping of lower plate rocks against the upper plate, and antithetic faults on upper and lower plates are all possible ways to create petroleum traps (fig. 19).

The amount of displacement along boundary faults seems to be greatest in the northern portion of the Nemaha. Calculation of the amount of overthrust possible depends on determining the dip angle of the thrust faults. For steeply dipping thrust (reverse) faults with a dip of $60^{\circ}$, the ratio of horizontal displacement to vertical displacement is $0.5: 1$, at $45^{\circ}$ it is $1: 1$, and at $30^{\circ}$ it is $2: 1$, and at $15^{\circ}$ it is $4: 1$. For low-angle thrust faults, the horizontal displacement can be many miles. As previously noted, the maximum calculated vertical displacement
(Cole, 1976) along the Nemaha in Nemaha County is about 3,300 ft, and is about 2,300 ft in Waubaunsee County. That would mean that a steeply dipping reverse fault in the northern segment could have a horizontal displacement of up to $1,650 \mathrm{ft}$, about $1 / 3 \mathrm{mi}$. If the fault were to dip $30^{\circ}$, the horizontal displacement would be up to $6,600 \mathrm{ft}$, and at $15^{\circ}$, up to $13,200 \mathrm{ft}$, or more than $2 \mathrm{mi}$. Thus the geometry of the fault is critical to exploration success. The preferred model for the Nemaha compromises with a dip of less than $45^{\circ}$, but more than $30^{\circ}$, not knowing if the plane is curved or flat (fig. 20).

Existing oil pools in the northern portion of the Nemaha are apparently locally sourced by generation within the Forest City basin. About 47 million barrels of oil have been produced from existing fields along the Nemaha trend in the northern 11-county area. Simpson, Maquoketa, Viola, and Hunton rocks are the major target reservoirs; the Arbuckle is absent. 


\section{STRUCTURAL MODEL TYPES}

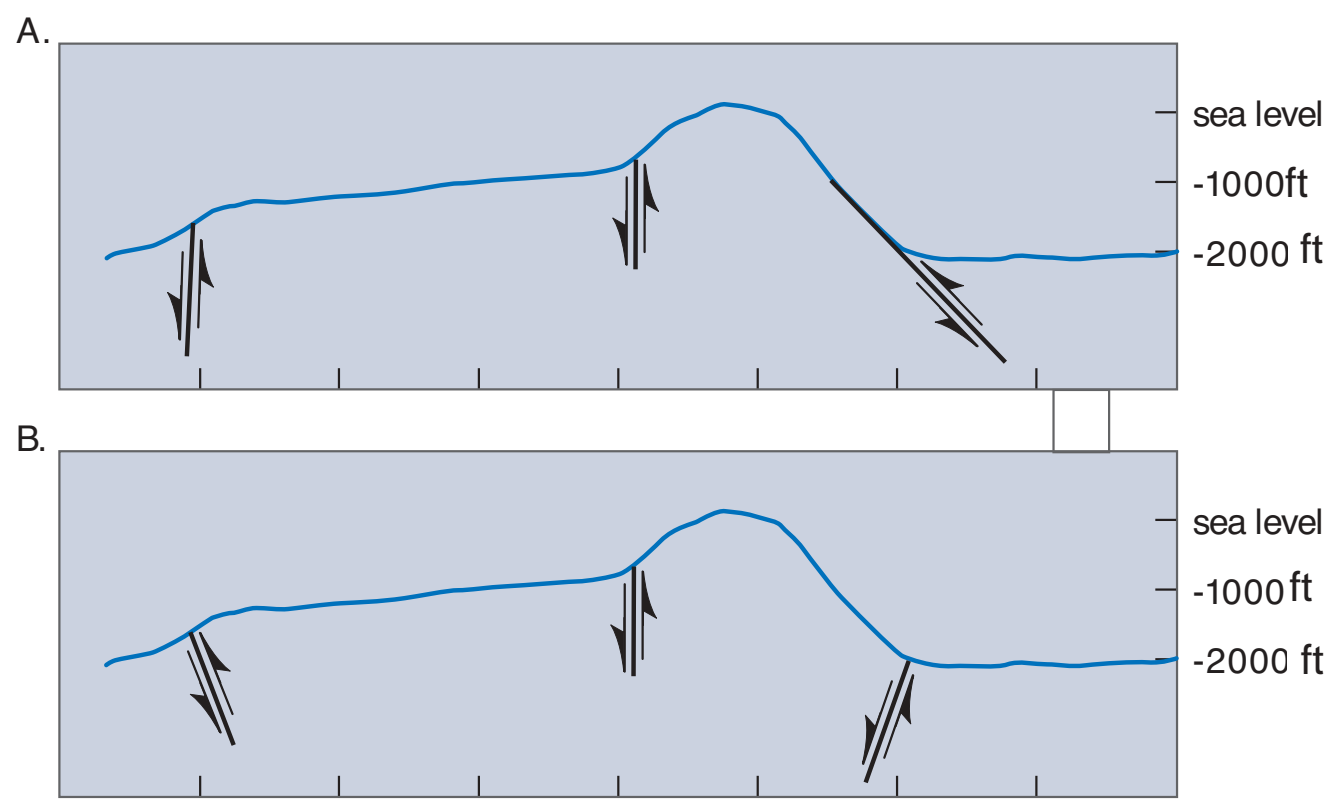

C.

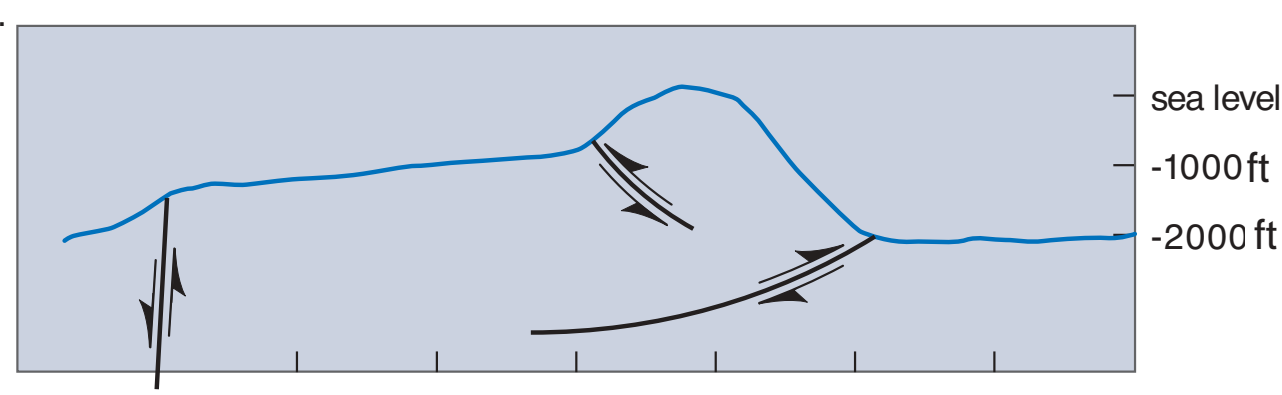

D.

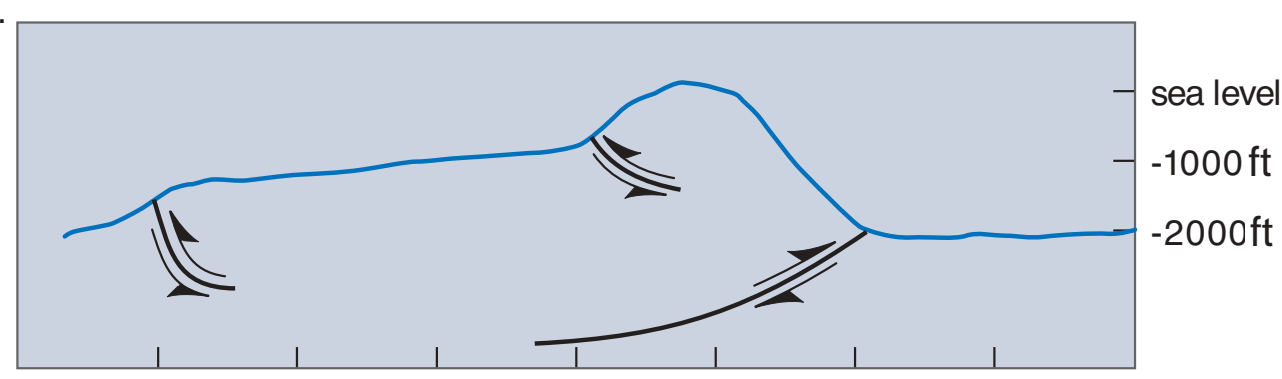

E.

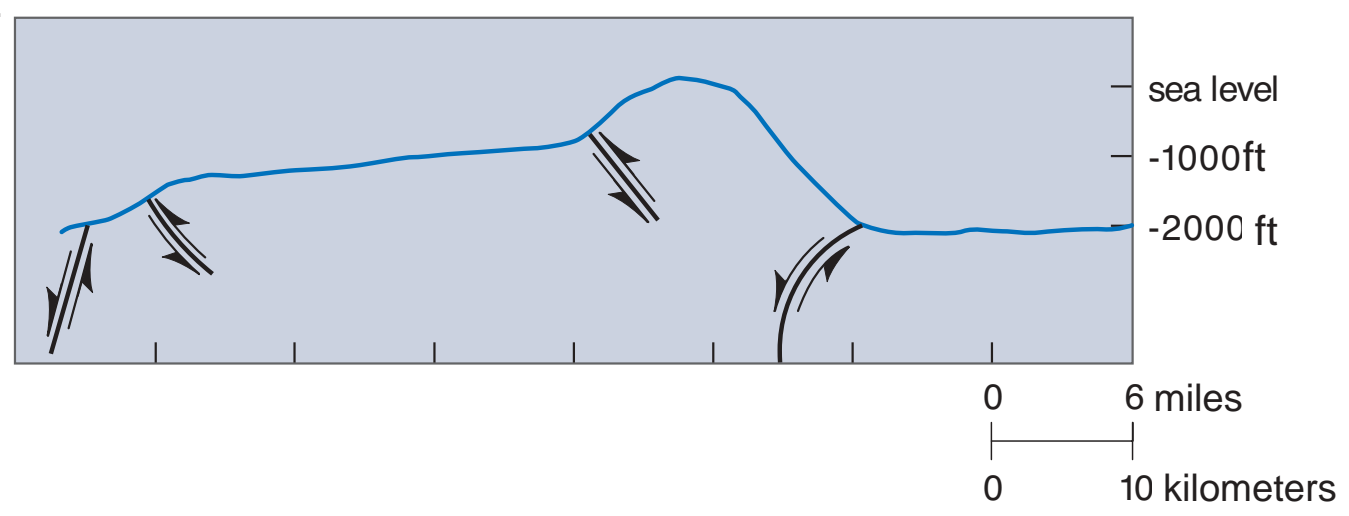

FIGURE 17. Possible models of fault movements across the Nemaha. Vertical exaggeration 1:47. A. Illustration of common perception of normal fault geometry. B. Steeply dipping reverse faults. C. Eastern margin thrust fault with backthrust and normal faults to the west. D. Thrust faulted eastern and western margins. E. Upthrust eastern margin. 


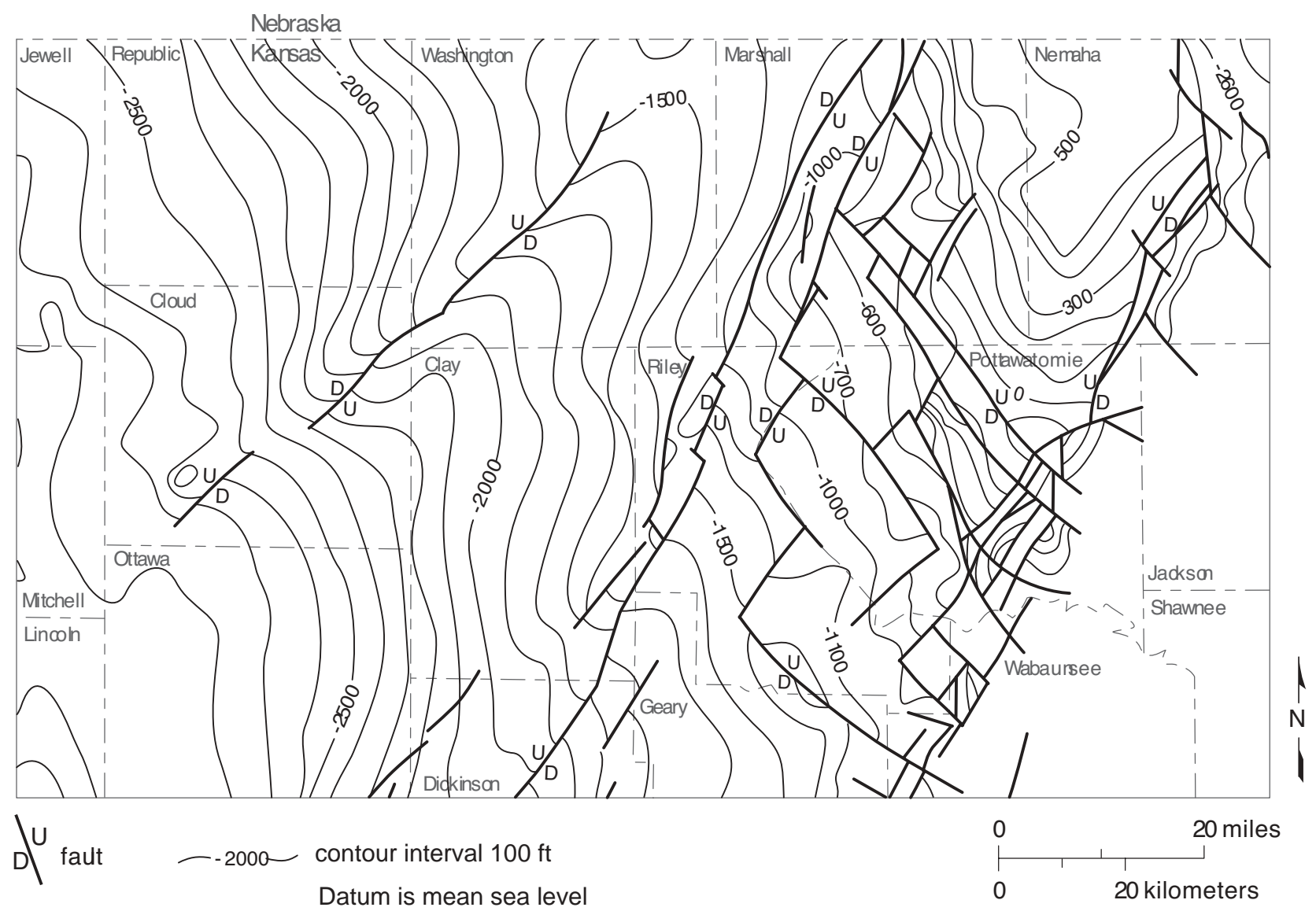

FIGURE 18. Map showing detailed faulting in extreme northeastern Kansas subsurface, including relative directions of motion that can be measured and interpreted from subsurface data. Direction of dip of fault planes is not indicated. From Berendsen (1999).

Further south, displacement decreases along the Nemaha. Migration of oil from the Ouachita basin (Chattanooga source) and from the Anadarko basin (Arbuckle source) may provide copious petroleum. Arbuckle through Mississippian reservoirs are potential prospective producing horizons if subthrust traps exist (Newell et al., 1987). Arbuckle reservoirs would be the prime target (Arbuckle is absent in extreme northern Kansas along the Nemaha).

Traps are difficult to locate with existing seismic technology, because the velocity differences are not large between carbonate rocks in many of these units and the granites of the Nemaha. Prospecting will require detailed seismic mapping of the edge of the Nemaha to locate cross structures and other indicators of subthrust potential traps. It is possible that detailed seismic surveys may detect thrust faults at depth, as seen in the COCORP data.

Recognition of once-submerged "up-up" corners of wrench-faulted blocks is another Nemaha-associated potential trap type. The reservoir quality in carbonate beds deposited on slightly elevated blocks is more likely to be enhanced by virtue of greater mechanical energy of shallower waters during deposition, which may increase the likelihood of diagenetic porosity enhancement. While not invariate, it has been a useful exploration tool in carbonate basins. Detailed and large-scale potential-fields (gravity and magnetic) measurements also may be useful. Detailed studies may be able to differentiate between sedimentary and granitic rocks, whereas regional data generalizes small structures and is not capable of distinguishing small differences in density and magnetic susceptibility.

The tool of last resort may be the least expensive and most definitive diagnostic tool, exploratory drilling, particularly in the northern segment where the top of the Nemaha is only a few hundred feet below the surface, and total depth through the prospective thrust sheet could be as little as 3,000 ft. Although industry economics currently do not permit expenditures on high-risk drilling, a consortium of industry and state and federal governments might be able to afford to test the thrust hypothesis with three strategically placed holes spaced along the front of the Nemaha. Any such program must recognize the complex faulting that occurs along the front. A successful new play would pay significant tax and economic-development dividends. 
A.

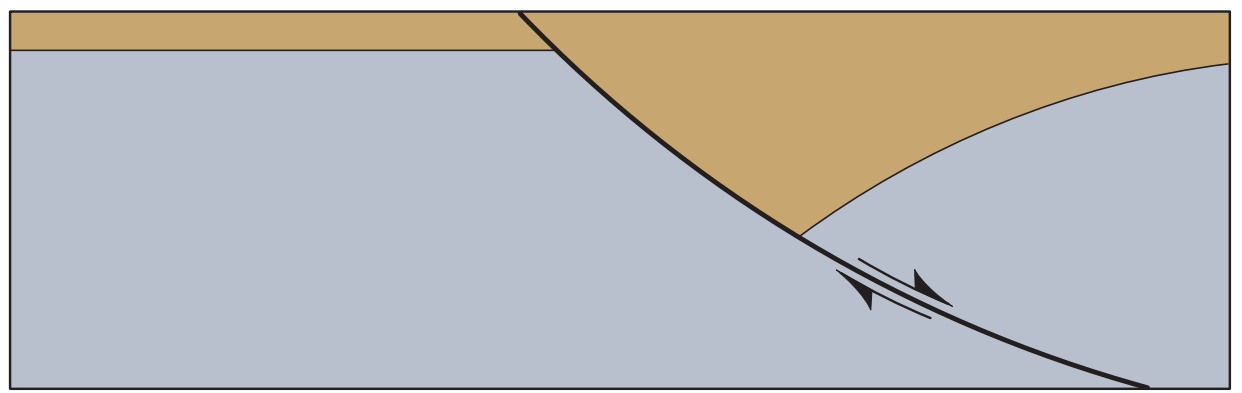

B.

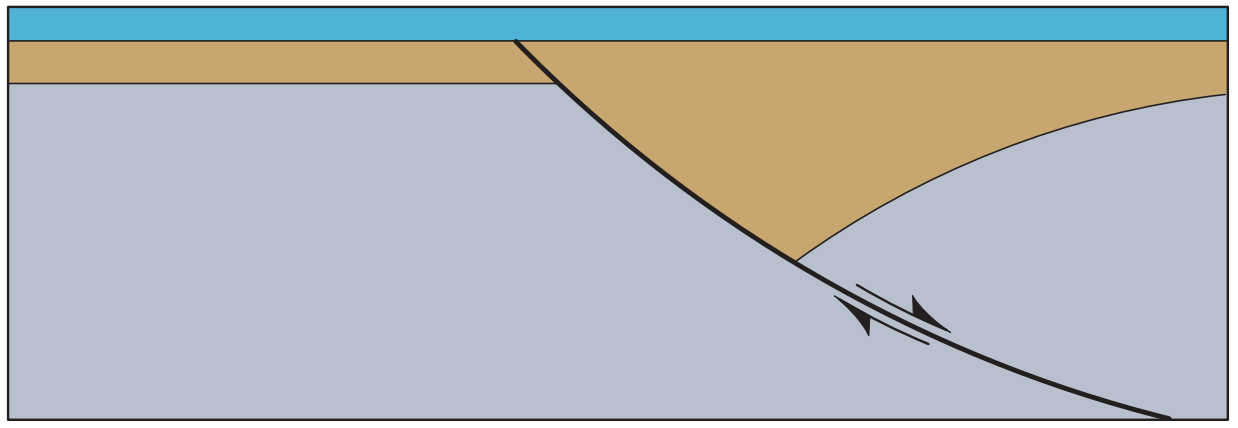

C.

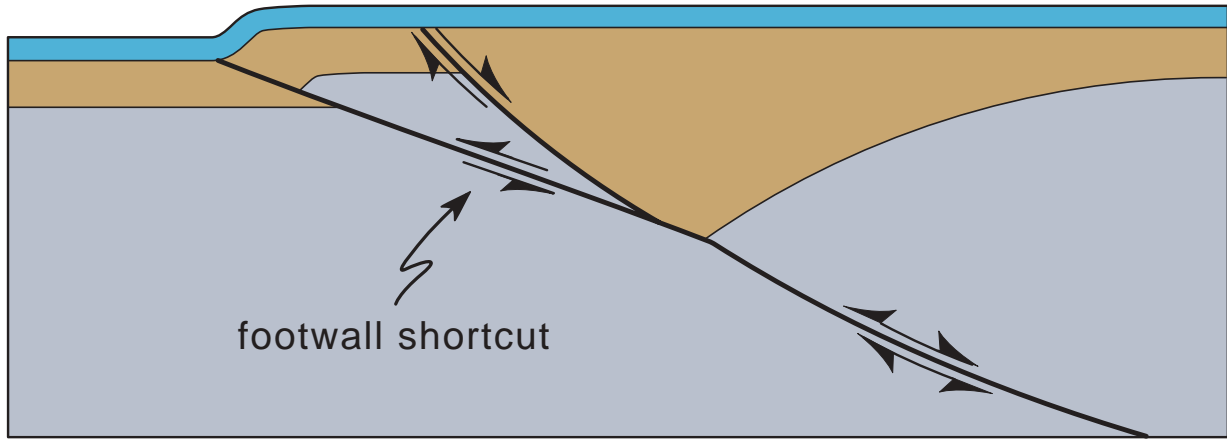

syn-rift sediments post-rift sediments

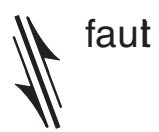

FIGURE 19. Generation of traps by reversal of motion, redrawn from Bump (2003). A. Primary normal faulting. B. Sedimentation over primary fault. C. Reversal of motion and creation of slices and "shortcuts."

\section{Summary}

This paper has attempted to synthesize what is known about the Precambrian geology of Kansas and to interpret Precambrian tectonic history that may be pertinent to further development of the Kansas oil and gas resource base. One assumption is that precursor Precambrian structures affect the deposition and diagenesis of younger sedimentary bodies and that precursor structures can be reactivated, although the sense of direction may be inverted. It is clear from both new mapping (plate 1) and from the literature that there are many basement faults in Kansas, occupying two significant directional trends, north-northeast and northwest.
Several tectonic episodes deformed the cratonic rocks of Kansas. Northern province rocks (Southern Yavapai Province of CD-ROM working group, 2002) were deformed approximately 1.6 b.y.B.P., and southern province rocks (Matzatsal Province of CD-ROM working group, 2002) were deformed approximately 1.4 b.y.B.P., both apparently by a series of compression events that welded successive bodies of crust to the craton.

A subsequent rifting event at about 1.1 b.y.B.P. created the Midcontinent Rift System, which stretches from Oklahoma to Lake Superior and created the north- 
A.

STRUCTURAL MODEL TYPES

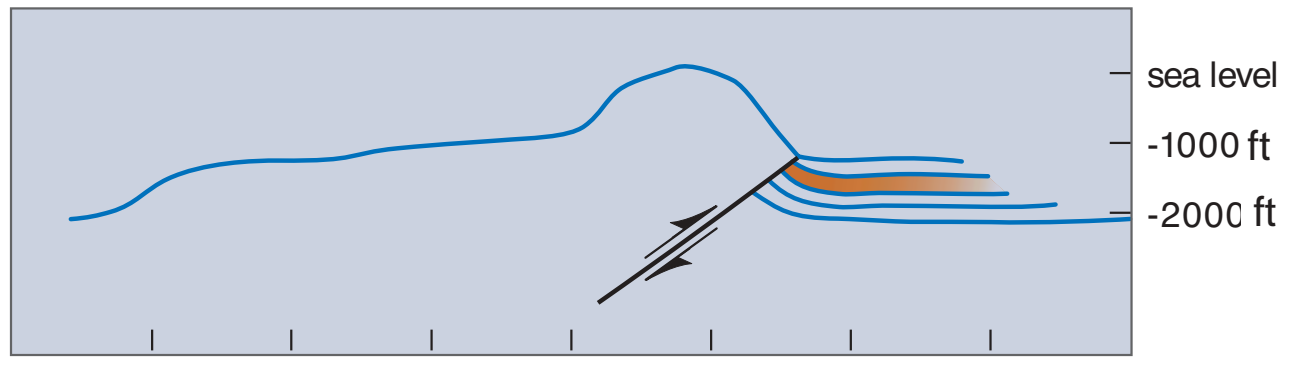

B.

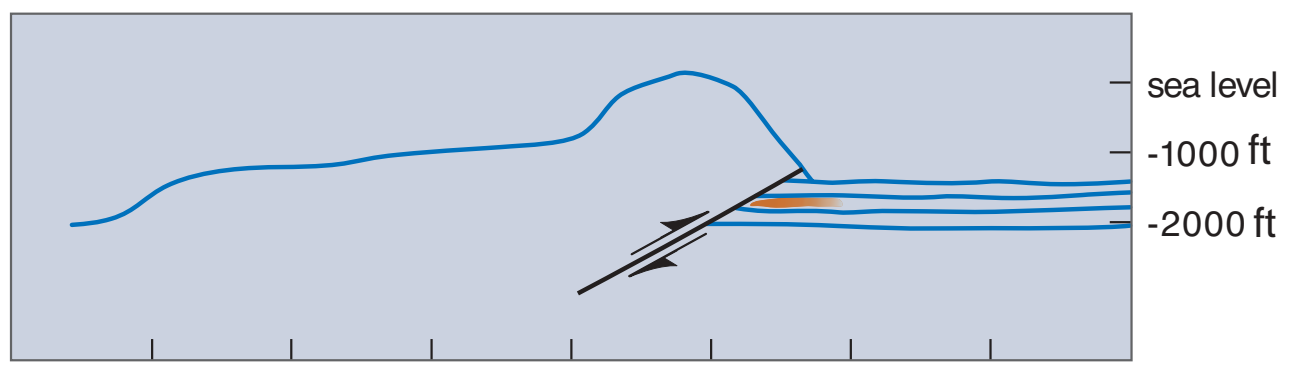

C.

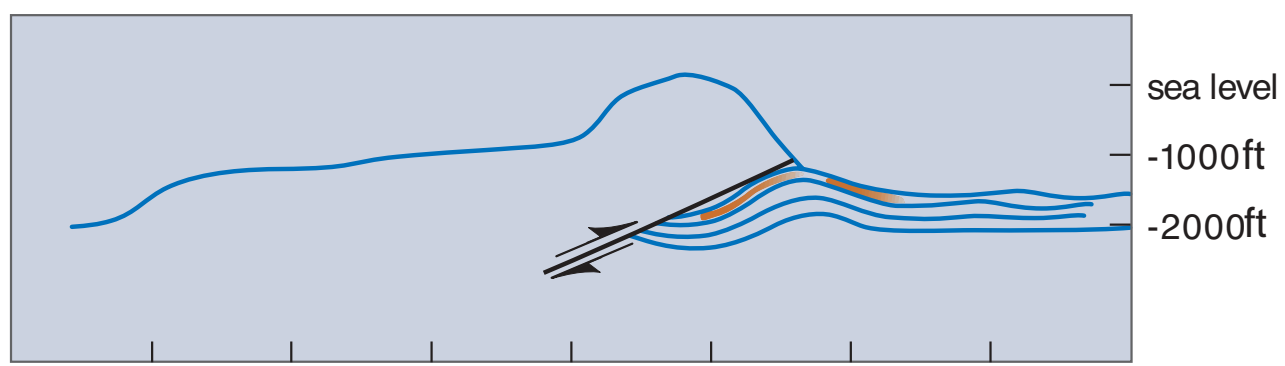

D.

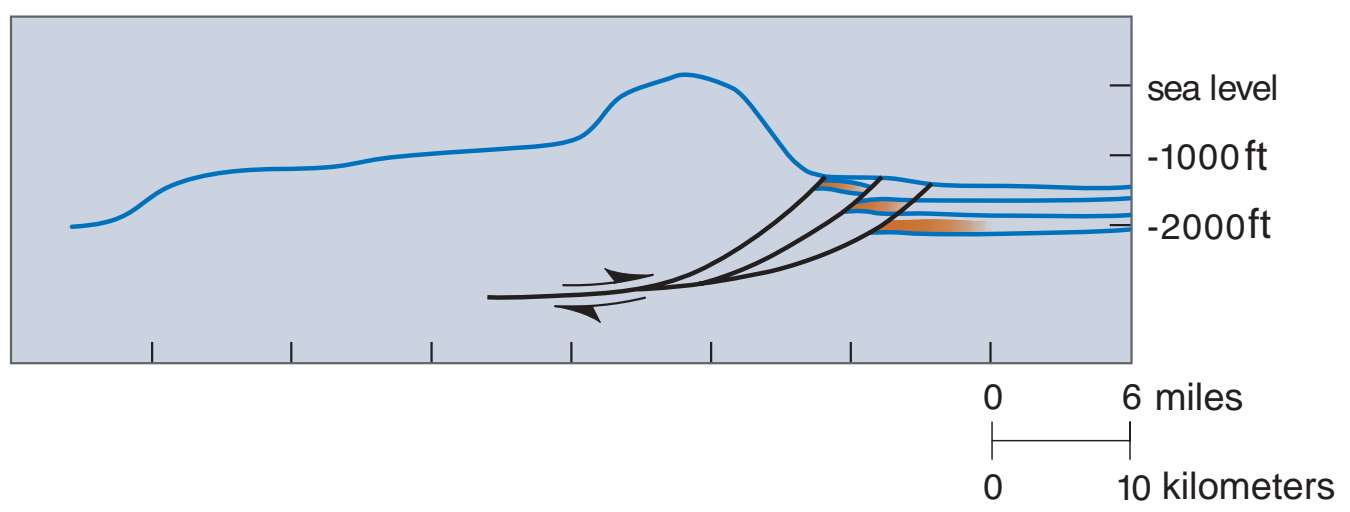

FIGURE 20. Structural model types that are possible along the Nemaha. A. Simple upturned drag, potential reservoir sealed at fault plane. B. Truncated reservoir beds. C. Antithetic fold in front of thrust plane. D. Reservoir sliced into segments by secondary faults. 
A.

\section{PREFERRED MODEL}

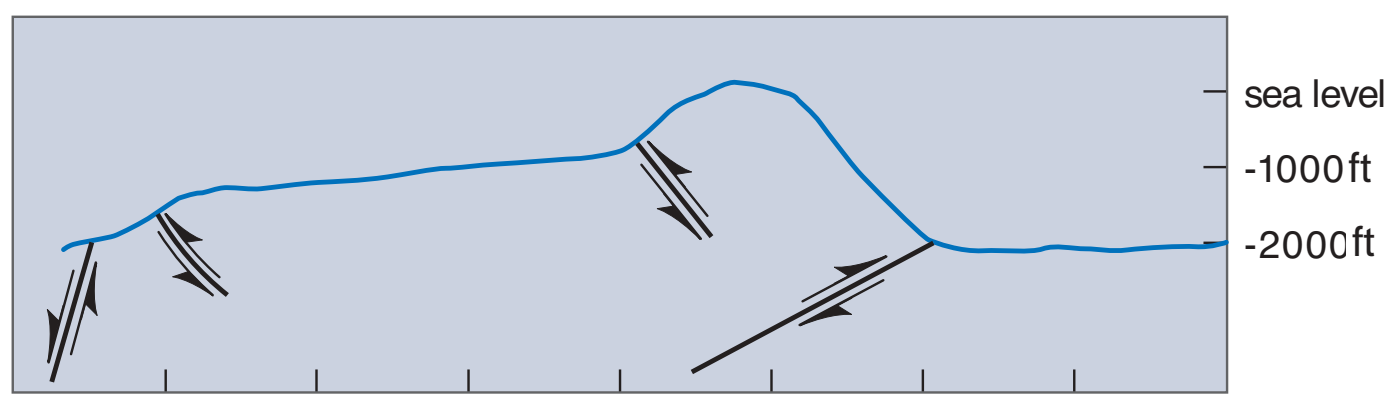

B.

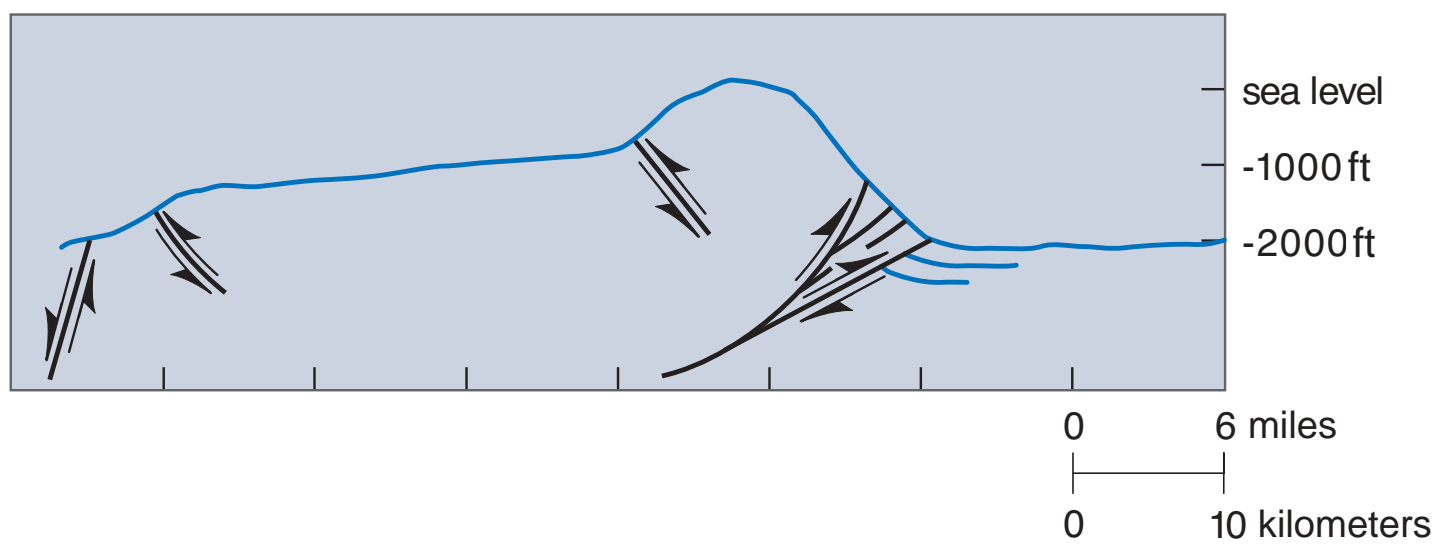

FIGURE 21. A. Simplified diagrammatic model of Nemaha fault geometry preferred by this study. The most likely new traps will be along the eastern, or frontal, edge of the Nemaha. Traps possibly could be located in residual Paleozoic rocks under thrusts on the western margins, but charging of those possible traps is less likely. B. More complex diagrammatic model showing assumed complexity along the eastern margin of the thrust.

northeast tectonic trend. Estimates are that there are more than 20,000 ft of rift fill in Kansas, including basalts, basic sills, and arkosic clastic detritus.

A late-rift-phase compression event occurred, prior to the deposition of the Upper Cambrian Reagan Sandstone, resulting in thrust faulting within the graben that displaced graben contents at least 6 mi horizontally and about $1 \mathrm{mi}$ vertically. This faulting is not reflected in the Paleozoic cover. Thousands of feet of detrital sediments were deposited in basins flanking the uplifted or overthrust basalt ridge.

Northwest-trending faults must have been fractured by this time, creating the Central Kansas uplift at the margin of the two major old Precambrian lithologic and age provinces, and offsetting the Nemaha structure faults. Recently encountered thick accumulations of sandstone along one of these faults in eastern Kansas argue for both vertical and horizontal displacement. There has been renewed movement along these fractures during Mississippian and Pennsylvanian time.
Minor structural movements have been identified in lower Paleozoic rocks, at a minimum corresponding to the major cratonic sequence unconformities. The last significant tectonic episode is the Ancestral Rocky Mountain episode, occurring during latest Mississippian and early Pennsylvanian time. This episode created a total of over $3,000 \mathrm{ft}$ vertical displacement along the Nemaha structure, the eastern border of the Midcontinent Rift. The nature of the faults and other evidence cited herein strongly suggests that the eastern and western margins of the Nemaha are reverse or thrust faulted. These faults may conceal significant petroleum accumulations.

The juncture of north-northeast of the Midcontinent Rift and the northwest faults that have created the Central Kansas uplift apparently shunted petroleum migrating from the southeast, south and southwest, creating a migration shadow in the Salina basin to the north. The same shunts helped charge oil fields along the southern Nemaha, the entire Central Kansas uplift, and perhaps some fields in southern Nebraska. Previous literature had suggested there was insufficient oil generated to charge the Salina basin, but the presence of the Sleepy Hollow 
field in Nebraska argues that there was sufficient petroleum, but limited migration access.

The major conclusion of this paper is that there may be a potential new oil play to be made by exploring under the Nemaha. Although the boundary faults of the Nemaha are partly strike slip, the major measurable offset is vertical. Earthquake history, Precambrian structural history, drilled duplicated sections, and theoretical restorations of movements suggest thrust or reverse faulting be considered in evaluating the Nemaha Ridge structure. Models suggest that the amount of overthrust on the eastern flank can range between 1,650 ft (503 m) and over $2 \mathrm{mi}(3.2 \mathrm{~km})$. Such displacement can easily accommodate slices of Paleozoic reservoir rocks in trap position. Fault burial of Arbuckle and Simpson rocks could enhance local oil generation by placing these rocks within the oil window.

\section{Acknowledgments and Author's Note}

The major contribution of this work is to bring a number of disparate elements together, describe their interplay, and describe potential benefit to the industry and to the Kansas economy by virtue of new interpretation. This work, although articulated by one writer, is the work of many people. Besides the citations of preceding literature, debates, discussion, and assistance from W. Lynn Watney, D. F. Merriam, and K. David Newell were vital to understanding many of the complexities of Kansas geology and a guide to the voluminous literature. Susan Nissen provided a needed viewpoint and material assistance in the interpretation of COCORP seismic data. Janice Sorensen kept filling my request for ever more literature, some from remote sources. Gina Ross persevered over the preparation of plate 1, managed to find a way to overlay the Precambrian subsurface on modern drainage without which plate 1 could not have been prepared, and created the final product. Pat Acker has always prepared my illustrations with skill, artistry, and timeliness; she has done so again. I thank Larry Skelton who reviewed this manuscript and made many good suggestions for its improvement, and Marvin P. Carlson of the Nebraska Geological Survey Division, who suggested significant manuscript revisions and with whom I carried on an extensive dialogue about the geologic history of the Midcontinent rift. Marlan Downey, Larry Richardson, and John Rold reviewed the manuscript and made many helpful suggestions for its improvement. All these contributions are appreciated.

\section{To my colleagues:}

After years in the administration of this Survey, this project has led me to better appreciate the technical competence and creativity of the Survey's scientists and staff. I have read some of the most creative and solid conceptual science about the geology of Kansas and its place in the greater North American craton ever written, by my esteemed colleagues. The efficiency and skills of our staff to provide the materials, information, and expertly created products necessary for this project continues to amaze me. I thought I appreciated you and your work from my previous perspective. Now I much better understand what you do for Kansas. Thank you!

\section{References}

Baars, D. L., 1966, Pre-Pennsylvanian paleotectonics-Key to basin evolution and petroleum occurrences in Paradox basin, Utah and Colorado: American Association of Petroleum Geologists Bulletin, v. 50, p. 2,082-2,111.

Baars, D. L., 1995, Basement tectonic configuration in Kansas; in, Geophysical Atlas of Selected Oil and Gas Fields in Kansas, N. L. Anderson and D. E. Hedke, eds.: Kansas Geological Survey and Kansas Geological Society, Bulletin 237, p. 7-9.

Baars, D. L., and Watney, W. L., 1991, Paleotectonic control of reservoir facies; in, Sedimentary Modeling: Computer Simulations and Methods for Improved Parameter Definition, E. K. Franseen, W. L. Watney, C. G. St. C. Kendall, and W. Ross, eds.: Kansas Geological Survey, Bulletin 233, p. 253-262.

Baars, D. L., Thomas, W. A., Drahovzal, J. A., and L. C. Gerhard, 1995, Preliminary investigations of basement tectonic fabric of the conterminus USA; in, Basement Tectonics, R. W. Ojakangas et al., eds.: Kluwer Academic Publishers, Netherlands, p. 149-158.

Berendsen, P., 1997, Tectonic evolution of the Midcontinent Rift System in Kansas; in, Middle Proterozoic to Cambrian Rifting, Central North America, R. W. Ojakangas, A. B. Dickas, and J. C. Green, eds.: Geological Society of America, Special Paper 312, p. 235-241.

Berendsen, P., 1999, Kansas Geological Survey's new initiative in the Manhattan 1 degree x 2 degree quadrangle, northeastern Kansas; in, Transactions of the American Association of Petroleum Geologists Midcontinent Section Meeting, D. F. Merriam, ed.: Kansas Geological Society and Kansas Geological Survey, Open-file Report 99-28, p. 125-133.

Berendsen, P., and Blair, K., 1986, Subsurface structural maps over the CNARS with discussion: Kansas Geological Survey, Subsurface Geology Series 8, 20 p., 7 maps.

Berendsen, P., Borcherding, R. M., Doveton, J., Gerhard, L., Newell, K. D., Steeples, D., and Watney, W. L., 1988, Texaco Poersch \#1, Washington County, KansasPreliminary geologic report of the pre-Phanerozoic rocks: Kansas Geological Survey, Open-file Report 8822, $116 \mathrm{p}$.

Bickford, M. E., Harrower, K. L., Nusbaum, R. L., Thomas, J. J., and Nelson, G. E., 1979, Preliminary geologic map of the Precambrian basement rocks of Kansas: Kansas Geological Survey, Map M-9, scale 1:500000

Bickford, M. E., Van Schmus, W. R., and Zietz, I., 1986, Proterozoic history of the midcontinent region of North America: Geology, v. 14, p. 492-496. 
Bump, Alexander P., 2003, Reactivation, trishear modeling, and folded basement in Laramide uplifts-Implications for origins of intra-continental faults; GSA Today, v. 13, no. 3, p. $4-10$.

Bunte, A. S., and Fortier, L. R., 1941, Nikkel Pool, McPherson and Harvey counties, Kansas; in, Stratigraphic Type Oil Fields-A Symposium, A. E. Levorson, ed.: American Association of Petroleum Geologists, Tulsa, OK, p. 105117.

Burchett, R. R., Wilson, F. W., Anderson, R. R., and Kisvarsanyi, E. B., 1983, Precambrian configuration map of Forest City basin and adjacent areas, of Iowa, Kansas, Missouri and Nebraska: Nebraska Geological Survey, Lincoln.

Burgess, P. M., Gurnis, M., and Moresi, L., 1997, Formation of sequences in the cratonic interior of North America by interactions between mantle, eustatic, and stratigraphic processes: Geological Society of America, Bulletin, v. 108, p. $1,515-1,535$.

Burruss, R. C., and Hatch, J. R., 1989, Geochemistry of oils and hydrocarbon source rocks, greater Anadarko basinEvidence for multiple sources of oils and long distance oil migration; in, Anadarko Basin Symposium 1988, K. S. Johnson, ed.: Oklahoma Geological Survey, Circular 90, p. 53-64.

Carlson, M. P., 1997, Tectonic implications and influence of the Midcontinent Rift System in Nebraska and adjoining areas; in, Middle Proterozoic to Cambrian Rifting, Central North America, R. W. Ojakangas, A. B. Dickas, and J. C. Green, eds.: Geological Society of America, Special Paper 312, p. 231-234.

Carlson, M. P., 1999, Transcontinental Arch-A pattern formed by rejuvenation of local features across central North America: Tectonophysics, v. 305, p. 225-233.

Carlson, M. P., 2001, Island arcs, accretionary terranes and midcontinent structure-New understandings of the geologic architecture of the U. S. midcontinent: Resource Notes, Conservation and Survey Division, Lincoln, Nebraska, v. 15, no. 1, p.15-18.

Carlson, M. P., and Treves, S. B., 2000, The Precambrian history of Nebraska and adjacent regions-A record of the accretionary growth of North America; in, VariscanAppalachian Dynamics-The Building of the Upper Paleozoic Basement: Basement Tectonics 15, A Coruna, Spain, Program and Abstracts, p. 75-78.

Carr, T. R., 2002, Kansas oil and gas production forecasts: Kansas Geological Survey, Open-file Report 2002-57, 17 p.

Carr, T. R., Hopkins, J., Anderson, N. L., and Hedke, D. E., 1995, Case history of Hampton field (Arbuckle Group).Rush County, Kansas; in, Geophysical Atlas of Selected Oil and Gas Fields in Kansas, N. L. Anderson and D. E. Hedke, eds.: Kansas Geological Survey and Kansas Geological Society, Bulletin 237, p.145-152.

CD-Rom Working Group, 2002, Structure and evolution of the lithosphere beneath the Rocky Mountains-Initial results from the CD-ROM experiment: GSA Today, v. 12, no. 2, p. 4-10.

Cole, V. B., 1976, Configuration of the top of the Precambrian rocks in Kansas: Kansas Geological Survey, Map M-7, scale 1:500000

Collins, D., Gerhard, L., Watney, W., Carr, T., and K. Newell, 1994, Potential for discovery and production from the
Kansas Crude Oil Resource Base: Kansas Geological Survey, Open-file Report 94-30, 9 p.

Condra, G. E., 1927, Stratigraphy of the Pennsylvanian System in Nebraska: Nebraska Geological Survey, v.1, 2nd series, $291 \mathrm{p}$.

Gay, S. P., Jr.,1995, Basement control of selected oil and gas fields in Kansas as determined by detailed residual aeromagnetic data; in, Geophysical Atlas of Selected Oil and Gas Fields in Kansas, N. L. Anderson and D. E. Hedke, eds.: Kansas Geological Survey and Kansas Geological Society, Bulletin 237, p. 10-16.

Gay, S. P., Jr., 1999, Strike-slip, compressional thrust-fold nature of the Nemaha system in eastern Kansas and Oklahoma; in, Transactions of the American Association of Petroleum Geologists Midcontinent Section Meeting, D. F. Merriam, ed.: Kansas Geological Society and Kansas Geological Survey, Open-file Report 99-28, p. 39-50.

Gay, S. P., Jr., 2003a, The Nemaha trend-A system of compressional thrust-fold, strike-slip structural features in Kansas and Oklahoma, Part 1: The Shale Shaker, v. 54, no.1, p. 9-17.

Gay, S. P., Jr., 2003b, The Nemaha trend-A system of compressional thrust-fold, strike-slip structural features in Kansas and Oklahoma, Part 2 (Conclusion): The Shale Shaker, v. 54, no. 2, p. 39-49.

Gerhard, L. C., 1967, Paleozoic geologic development of the Canon City embayment, Colorado: American Association of Petroleum Geologists, Bulletin, v. 51, no. 11, p. 2,260-2,280.

Gerhard, L.C., and Anderson, S. B., 1979, Oil exploration and development in the North Dakota Williston basin: North Dakota Geological Survey, Miscellaneous Series no. 57, 19 p.

Gerhard, L.C., Anderson, S. B., and LeFever, J., 1987, Structural history of the Nesson anticline, North Dakota; in, Williston Basin-Anatomy of a Cratonic Oil Province, Peterson et al., eds.: Rocky Mountain Association of Geologists, p. 337-353.

Gerhard, L. C., Anderson, S.B., Carlson, C., and LeFever, J., 1982, Geological development, origin, and energy and mineral resources of the Williston basin, North Dakota: American Association of Petroleum Geologists, Bulletin, v. 66 , no. 8, p. 989-1,020.

Gerhard, L. C., and Anderson, S. B., 1988, The Williston basin-Sedimentary cover - North American CratonU.S.: Geological Society of America, Chapter 9, Geology of North America, D-2, p. 221-242.

Gerhard, L. C., Anderson, S. B., and Fischer, D. W., 1991, Petroleum geology of the Williston basin; in, Petroleum Geology of Interior Cratonic Basins, M. Leighton, D. Kolata, D. Oltz, and J. Eidel, eds.: American Association of Petroleum Geologists, Memoir 51, Chapter 29, p. 507-559.

Gerhard, L. C., Brady, L., Watney, W. L., and Collins, D., 1992, Fossil energy resources in Kansas, 1992: Kansas Geological Survey, Open-file Report 92-9, 53 p.

Gussow, W. C., 1954, Differential entrapment of oil and gas-A fundamental principle: American Association of Petroleum Geologists, Bulletin, v. 38, p. 816-853.

Hambleton, W. W., 1989, Some late night thoughts about geology and geophysics; in, Geophysics in Kansas, D. Steeples, ed.: Kansas Geological Survey, Bulletin 226, p. 303-305. 
Haraldson, N. L., Knapp, R. W., and Newell, K. D., 1995, Seismic response of the east flank of the Central Kansas uplift, Rice County, Kansas; in, Geophysical Atlas of Selected Oil and Gas Fields in Kansas, N. L. Anderson and D. E. Hedke, eds.: Kansas Geological Survey and Kansas Geological Society, Bulletin 237, p. 47-52.

Haworth, Erasmus, and Bennett, John, 1908, Chapter 3, General Stratigraphy; in, Special Report on Oil and Gas: The University Geological Survey of Kansas (Kansas Geological Survey), v. IX, p. 57-159.

Inden, Richard, and Frush, Penny, 2002, Examples of aeromagnetic exploration in intracratonic basins: PI/ Dwights Plus Drilling Wire, Rocky Mountain Regions, Northern Edition/Section 1, Denver, p. 7-12

Jewett, J. M., 1951, Geologic structures in Kansas: Kansas Geological Survey, Bulletin 90, part 6, 172 p.

Kansas Geological Survey, 2000, Generalized geologic map of Kansas: Kansas Geological Survey,

Kruger, J. M., 1996, On-line gravity and magnetic maps of Kansas: Kansas Geological Survey, Open-file Report 9651, http://www.kgs.ku.edu/PRS/PotenFld/potential.html

Lam, C.-K., and Yarger, Harold, 1989, Bouguer gravity map of Kansas; in, Geophysics in Kansas, D. Steeples, ed.: Kansas Geological Survey, Bulletin 226, pocket.

Lee, Wallace, 1943, The stratigraphy and structural development of the Forest City basin in Kansas: Kansas Geological Survey, Bulletin 51, 142 p.

Lyons, P. L., 1959, The Greenleaf Anomaly, a significant gravity feature; in, Symposium on Geophysics in Kansas, W. W. Hambleton, ed.: Kansas Geological Survey, Bulletin137, p. 105-120.

Marshak, Stephen, and Paulson, Timothy, 1996, Midcontinent U. S. fault and fold zones-A legacy of Proterozoic intracratonic extensional tectonism?: Geology, v. 245, p. 151-154.

McBee, William, 2003, Nemaha strike-slip fault zone: American Association of Petroleum Geologists, Search and Discovery, 6 p., http://www.searchanddiscovery.net/ documents/2003/mcbee/index.htm

Merriam, D. F., 1956, History of earthquakes in Kansas: Seismological Society of America, Bulletin, v. 46, no. 2, p. $87-96$

Merriam, D. F., 1960, Preliminary regional structural contour map on top of Mississippian rocks in Kansas: Kansas Geological Survey, Oil and Gas Investigations 22, map.

Merriam, D. F., 1963, The geologic history of Kansas: Kansas Geological Survey, Bulletin 162, 307 p.

Merriam, D. F., and Smith, P., 1961, Preliminary regional structural contour map on top of Arbuckle rocks (Cambrian-Ordovician) in Kansas: Kansas Geological Survey, Oil and Gas Investigations 25, map.

Merriam, D. F., Winchell, R.L., and Atkinson, W.R., 1958, Preliminary regional structural contour map on top of the Lansing Group (Pennsylvanian) in Kansas: Kansas Geological Survey, Oil and Gas Investigations 19, map.

Moore, R. C., 1918, Geologic history of crystalline rocks in Kansas: American Association of Petroleum Geologists, Bulletin, v. 2, p. 98-113.

Moore, R. C., and Haynes, W. P., 1917, Oil and gas resources of Kansas: Kansas Geological Survey, Bulletin 3, p. 140-173.

Newell, K. D., 1996, Lithofacies and diagenesis of the Upper Ordovician Viola Formation on the Central Kansas arch and adjacent areas: Kansas Geological Survey, Open-file Report 96-10, 610 p.

Newell, K. D. and Hatch, J. R., 1999, Petroleum geology and geochemistry of a production trend along the McPherson anticline, in central Kansas, with implications for long- and short-distance oil migration; in, Transactions of the American Assocociation of Petroleum Geologists Midcontinent Section Meeting, D. F. Merriam, ed.: Kansas Geological Society and Kansas Geological Survey Openfile Report 99-28, p. 22-28.

Newell, K. D., Watney, W. L., Chang, S. W. L., and Brownrigg, R. L., 1987, Stratigraphic and spatial distribution of oil and gas production in Kansas: Kansas Geological Survey, Subsurface Geology Series 9, 86 p.

Price, L., 1980, Shelf and shallow basin oil as related to hotdeep origin of petroleum: Journal of Petroleum Geology, v. 3, p. 91-116.

Rich, J. L., 1931, Function of carrier beds in long-distance migration of oil: American Association of Petroleum Geologists, Bulletin, v. 15, p. 911-924.

Rich, J. L., 1933, Distribution of oil pools in Kansas in relation to pre-Mississippian structure and areal geology: American Association of Petroleum Geologists, Bulletin, v. 17, p. 793-815.

Roehl, Nelda, Knapp, R. W., and Newell, K. D., 1989, Seismicreflection study in Rice County,Kansas; in, Geophysics in Kansas, D. Steeples, ed.: Kansas Geological Survey, Bulletin 226, p. 81-94.

Serpa, L., Setzer, T., and Brown, L., 1989, COCORP seismicreflection profiling in northeastern Kansas; in, Geophysics in Kansas, D. Steeples, ed.: Kansas Geological Survey, Bulletin 226, p. 176.

Scott, R. W., 1966, New Precambrian (?) formation in Kansas: American Association of Petroleum Geologists, Bulletin, v. 50, p. 380-384.

Silverman, M. R., ed., 2002, Recent advances in the use of gravity and magnetics for petroleum exploration: IHS Energy Group Petroleum Frontiers, Denver, CO, 84 p.

Smith, R. K., and Anders, E. L, Jr., 1951, Geology of the Davis Ranch oil pool, Wabaunsee County, Kansas: Kansas Geological Survey, Bulletin 90, pt. 2, p. 13-52.

Steeples, D. W., 1996, Earthquakes: Kansas Geological Survey, Public Information Circular 3, Lawrence, KS.

Van Schmus, W. R., 1992, Tectonic setting of the Midcontinent Rift System: Tectonophysics, v. 213, p. 1-15.

Van Schmus., W. R., and Bickford, M. E., 1981, Proterozoic chronology and evolution of the midcontinent region, North America; in, Precambrian Plate Tectonics, A. Kroner, ed.: Elsevier, Amsterdam, p. 261-296.

Van Schmus, W. R., Bickford, M. E., and Zietz, I., 1987, Early and Middle Proterozoic provinces in the central United States; in, Proterozoic Lithospheric Series, A. Kroner, ed.: American Geophysical Union, Proterozoic Lithospheric Series, v. 17, p. 43-68.

Van Schmus, W. R., Bickford, M. E., Sims, P. K., Anderson, R. R. , Shearer, C. K., and Treves, S. B., 1993, Proterozoic geology of the western midcontinent basement; in, Precambrian Coterminous U. S., J. C. Reed, Jr., M. E, Bickford, R. S. Houston, P. K. Link, D. W. Rankin, P. K. Sims, and W. R. Van Schmus, eds.: Geological Society of America, The Geology of North America, v. C-2, p. 239259. 
Van Schmus, W. R., Bickford, M. E., and Turek, A., 1996, Proterozoic geology of the east-central midcontinent basement; in, Basement and Basins of Eastern North America, B. A. van der Pluijm, and P. A. Catacosinos, eds.: Geological Society of America, Special Paper 308, p. 7-32.

Walters, R. F., 1958, Differential entrapment of oil and gas in Arbuckle dolomite of central Kansas: American Association of Petroleum Geologists, Bulletin, v. 42, p. 2,133-2,173.

Walters, R. F., 1991, Gorham oil field, Russell County, Kansas: Kansas Geological Survey, Bulletin 228, 111 p.

Wilson, F. W., and McCauley, J. R., 1989, The relationship of remote-sensing anomalies to the real world-Examples from the midcontinent and the CUSMAP study areas; in, U.S. Geological Survey-Missouri Geological Survey
Symposium-Mineral Resources Potential for the Midcontinent, Program and Abstracts, St. Louis, MO, April 11-12: U.S. Geological Survey, Circular 1043, p. 45.

Woelk, T. S., and Hinze, W. J., 1991, Model of the Midcontinent Rift System in northeastern Kansas: Geology, v.19, p. 277280.

Woelk, T. S., and Hinze, W. J., 1995, Midcontinent Rift System in northeastern Kansas; in, N. L. Anderson and D. E. Hedke, Geophysical Atlas of Selected Oil and Gas Fields in Kansas, Kansas Geological Survey and Kansas Geological Society, Bulletin 237, p. 22-27.

Yarger, Harold, 1989, Aeromagnetic map of Kansas; in, Geophysics in Kansas, D. Steeples, ed.: Kansas Geological Survey, Bulletin 226, pocket.

\section{PLATE 1 (follows): Preliminary lineament map of Kansas.}

